Article

\title{
Proeryptotic Activity of 4-Hydroxynonenal: A New Potential Physiopathological Role for Lipid Peroxidation Products
}

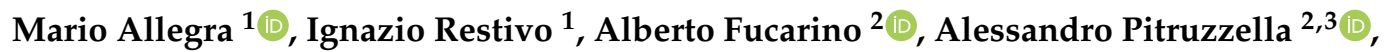 \\ Sonya Vasto ${ }^{1}$ (D), Maria Antonia Livrea ${ }^{1}$, Luisa Tesoriere ${ }^{1, *(\mathbb{D})}$ and Alessandro Attanzio ${ }^{1}$ (D) \\ 1 Dipartimento di Scienze e Tecnologie Biologiche, Chimiche e Farmaceutiche, Università di Palermo, \\ 90123 Palermo, Italy; mario.allegra@unipa.it (M.A.); ignazio.restivo@unipa.it (I.R.); \\ sonya.vasto@unipa.it (S.V.); maria.livrea@unipa.it (M.A.L.); alessandro.attanzio@unipa.it (A.A.) \\ 2 Dipartimento di Biomedicina, Neuroscienze e Diagnostica Avanzata, Università di Palermo, 90127 Palermo, \\ Italy; alberto.fucarino@unipa.it (A.F.); alessandro.pitruzzella@unipa.it (A.P.) \\ 3 Consorzio Universitario di Caltanissetta, Università di Palermo, 90127 Palermo, Italy \\ * Correspondence: luisa.tesoriere@unipa.it; Tel.: +39-091-2389-6824
}

Received: 18 April 2020; Accepted: 13 May 2020; Published: 16 May 2020

check for updates

\begin{abstract}
Background: Eryptosis is a physiological, apoptosis-like death of injured erythrocytes crucial to prevent premature haemolysis and the pathological sequalae generated by cell-free haemoglobin. When dysregulated, the process is associated to several inflammatory-based pathologies. 4-Hydroxy-trans-2-nonenal (HNE) is an endogenous signalling molecule at physiological levels and, at higher concentrations, is involved in the pathogenesis of several inflammatory-based diseases. This work evaluated whether HNE could induce eryptosis in human erythrocytes. Methods: Measurements of phosphatidylserine, cell volume, intracellular oxidants, $\mathrm{Ca}^{++}$, glutathione, ICAM- 1 , and ceramide were assessed by flow cytometry. Scanning electron microscopy evaluated morphological alterations of erythrocytes. Western blotting assessed caspases. $\mathrm{PGE}_{2}$ was measured by ELISA. Adhesion of erythrocytes on endothelial cells was evaluated by gravity adherence assay. Results: HNE in the concentration range between 10-100 $\mu \mathrm{M}$ induces eryptosis, morphological alterations correlated to caspase- 3 activation, and increased $\mathrm{Ca}^{++}$levels. The process is not mediated by redox-dependent mechanisms; rather, it strongly depends on $\mathrm{PGE}_{2}$ and ceramide. Interestingly, HNE induces significant increase of erythrocytes adhesion to endothelial cells (ECs) that are in turn dysfunctionated as evident by overexpression of ICAM-1. Conclusions: Our results unveil a new physiopathological role for HNE, provide mechanistic details of the HNE-induced eryptosis, and suggest a novel mechanism through which HNE could exert pro-inflammatory effects.
\end{abstract}

Keywords: 4-hydroxynonenal; lipid peroxidation products; eryptosis; prostaglandins; RBC; inflammation

\section{Introduction}

Eryptosis is a physiological, apoptosis-like, suicidal death of erythrocytes (RBC) [1]. Hallmark of the eryptotic process is the loss of membrane phospholipid asymmetry due to the translocation of the cell membrane phospholipid phosphatidylserine (PS) from the inner to the outer leaflet by $\mathrm{Ca}^{++}$-sensitive scramblase [2]. This process allows eryptotic RBCs to be recognized by macrophages, phagocytosed, degraded, and cleared from circulation.

Utterly distinct from the erythrocytic senescence, eryptosis ostensibly serves the same purpose as apoptosis, i.e., the disposal of defective cells without breaking cell membrane integrity and releasing eventual pro-inflammatory, cytosolic material to the extracellular environment. Eryptosis can be, 
therefore, envisaged as a preemptive measure of the body to reduce premature haemolysis of injured RBC, thus preventing the detrimental increase of cell-free haemoglobin in circulation [3].

Excessive eryptosis, however, has been implicated in a number of pathological conditions such as anaemia, renal and hepatic failure, sepsis, and malignancy [3-6]. Moreover, due to propensity of eryptotic RBC to adhere to endothelial cells (ECs), eryptosis has been involved in the pathogenesis of inflammatory and cardiometabolic diseases $[3,4]$.

Eryptosis is triggered by several pathophysiological cell stressors and orchestrated by a complex machinery of lipids, membrane proteins, ion channels, and cellular enzymes. In this regard, the increase of endocellular $\mathrm{Ca}^{++}$levels play a key role within the eryptotic process. It has, indeed, been shown that several proeryptotic stimuli can activate phospholipase $\mathrm{A}_{2}\left(\mathrm{PLA}_{2}\right)$ that releases arachidonic acid (AA), leading to prostaglandin endoperoxide synthase (PGHS) activation. The resulting increase of $\mathrm{PGE}_{2}$ levels then activates and opens nonselective cationic membrane (NSCM) channels, leading to an increment of $\mathrm{Ca}^{++}$endocellular levels that in turn activates several molecular targets including $\mathrm{Ca}^{++}$-dependent $\mathrm{K}^{+}$channels. The resulting membrane hyperpolarization increases the electrical driving force for $\mathrm{Cl}^{-}$exit, and the resulting cellular loss of $\mathrm{KCl}$, with osmotically obliged water efflux, determines RBC shrinkage [6]. On the other hand, $\mathrm{Ca}^{++}$influx, together with platelet activating factor $(\mathrm{PAF})$, activates membrane sphingomyelinase (SMase) responsible for the increase of ceramide levels that plays a key role in the apoptotic process [3,4]. Indeed, $\mathrm{Ca}^{++}$and ceramide are able to respectively activate scramblase and to inhibit flippases, involved in PS externalization. Finally, increase of $\mathrm{Ca}^{++}$ levels also activate cysteine-calpain endopeptidases responsible for the membrane blebbing that increases the adhesion capacity of RBC [7].

4-Hydroxy-trans-2-nonenal (HNE) is an $\alpha, \beta$-unsaturated aldehyde endogenously generated by the radical-mediated peroxidation of $\omega-6$ polyunsaturated fatty acids. Its reactive carbonyl moieties, together with the conjugated double bonds, generate two electrophilic centres (the carbonyl carbon atom and the $\beta$-carbon one), both of which can condense with suitable nucleophilic moieties of biological targets, such as proteins, DNA, and phospholipids [8,9]. Thanks to its ability to covalently modify biomolecules, HNE modulates many physiopathological processes [10] and its role highly depends on its concentrations. Indeed, if at physiological $(74 \mathrm{nM}$ to $1 \mu \mathrm{M})$ or at low/sublethal plasma concentrations (up to $10 \mu \mathrm{M}$ ) HNE acts as an endogenous signalling molecule, higher and toxic plasma levels $(20 \mu \mathrm{M}$ to $5 \mathrm{mM})$ are involved in the onset and propagation of several human diseases [8,9,11-17]. As a signalling molecule, HNE plays a key role in several regulatory mechanisms responsible for glutathione biosynthesis, insulin secretion, and stimulation of antioxidant enzymes $[10,18]$. On the other hand, toxic concentrations of HNE constitute one of the main driving forces in the development and progression of several inflammatory-based conditions [19-21]. Among these, atherosclerosis, neurological diseases, and metabolic syndrome risk factors (dyslipidaemias, insulin resistance, and obesity) have all been recently correlated to high HNE plasma levels in the range between 10 and 100 $\mu \mathrm{M}$ [22]. Covalent protein modifications, enzyme activity, and gene expression alterations by HNE are involved in the mechanisms underlying the above-cited pathological conditions.

In light of the mechanisms orchestrating the eryptotic process, strongly regarding membrane structure and function and considering the key role of HNE in membrane alterations supporting inflammatory-based pathologies [11], we here evaluated whether HNE at physiopathological concentrations could induce eryptosis in human RBCs. Mechanistic insights for the observed proeryptotic activity of HNE were investigated, and pathological relevance of the observed results were discussed.

\section{Materials and Methods}

Unless otherwise specified, all reagents and chemicals were from Sigma-Aldrich (Milan, Italy) and of the highest purity grade available.

\subsection{Red Blood Cells and Treatment}

Blood was collected from healthy volunteers ( $n=5$; age range between 23 and 65 years with physiological body mass index) with informed consent, and RBCs were immediately isolated by $20 \mathrm{~min}$ 
centrifugation at $2000 \times g$ at $4{ }^{\circ} \mathrm{C}$ over Ficoll (Biochrom KG, Berlin, Germany) gradient. RBCs $(0.4 \%$ haematocrit) were incubated at $37^{\circ} \mathrm{C}, 5 \% \mathrm{CO}_{2}$, and $95 \%$ humidity in Ringer solution containing $(\mathrm{mM})$ $125 \mathrm{NaCl}, 5 \mathrm{KCl}, 1 \mathrm{MgSO}_{4}, 32 \mathrm{~N}$-2-hydroxyethylpiperazine- $\mathrm{N}$-2-ethanesulfonic acid (HEPES)/NaOH, 5 Glucose, and $1 \mathrm{CaCl}_{2}$ at $\mathrm{pH} 7.4$ for the indicated time.

RBCs were treated for $24 \mathrm{~h}$ with HNE and were added in Ringer's solution at a final $0.1 \%(v / v)$ ethanol (EtOH) concentration. Preliminary experiments showed that, under these conditions, $\mathrm{EtOH}$ did not have any effect on cells and therefore control RBCs were incubated with $\mathrm{EtOH}$.

In selected experiments, RBCs either were incubated in Ringer's solution in the absence of $\mathrm{CaCl}_{2}$ and then treated with HNE or were preincubated for $1 \mathrm{~h}$ in Ringer's solution in the presence of $50 \mu \mathrm{M}$ Acetylsalicylic Acid (ASA) diluted in EtOH.

The recruitment of the healthy volunteers was conducted within the project "Discovery of molecular and genetic/epigenetic signatures underlying resistance to age-related diseases and comorbidities (DESIGN)" Bando 2015 Prot 20157ATSLF, funded by the Italian Ministry of Education, University, and Research. The study protocol was approved by the Ethic Committee of Palermo University Hospital (Nutrition and Longevity, No. 032017) The study was conducted in accordance with the Declaration of Helsinki and its amendments.

\subsection{Flow Cytometry}

\subsubsection{Measurement of Phosphatidylserine (PS) Externalization and Forward Scatter (FSC)}

RBCs were washed once in Ringer's solution, $\mathrm{pH} 7.4$, and adjusted at $1.0 \times 10^{6}$ cells $/ \mathrm{mL}$ with a binding buffer according to the manufacturer's instructions (eBioscience Inc., San Diego, CA, USA). In experiments designed to evaluate PS externalization, cell suspension $(100 \mu \mathrm{L})$ was incubated with $5 \mu \mathrm{L}$ Annexin V-FITC at room temperature in the dark for $15 \mathrm{~min}$. Samples of at least $1 \times 10^{4}$ cells were then analysed by flow cytometry (FACS) for both FSC and Annexin V-fluorescence intensity (the latter in fluorescence channel FL-1, with an excitation wavelength of $488 \mathrm{~nm}$ and an emission wavelength of $530 \mathrm{~nm}$ ), with an Epics XL ${ }^{\mathrm{TM}}$ flow cytometer, using Expo32 software, version 1.1C (Beckman Coulter, Fullerton, CA, USA).

\subsubsection{Measurement of Intracellular Reactive Oxygen and Nitrogen Species}

Level of Reactive Oxygen and Nitrogen Species (RONS) was monitored by measuring the fluorescence changes resulting from oxidation of dichloro-dihydro-fluorescein diacetate (DCF-DA). Briefly, $10 \mu \mathrm{M}$ fluorescence probe was added to $1.0 \times 10^{5}$ cells, $30 \mathrm{~min}$ before the end of the treatment, in the dark. Cells were collected by centrifugation $\left(2000 \times g, 4{ }^{\circ} \mathrm{C}, 5 \mathrm{~min}\right)$, washed, resuspended in PBS, and analysed as above reported.

\subsubsection{Measurement of Cytosolic $\mathrm{Ca}^{++}$}

Levels of intracellular $\mathrm{Ca}^{++}$was monitored by measuring the fluorescence changes of the cell-permeable dye fluo-3 AM resulting from its binding with $\mathrm{Ca}^{++}$. Briefly, $10 \mu \mathrm{M}$ fluorescence probe was added to $1.0 \times 10^{5}$ cells $30 \mathrm{~min}$ before the end of the treatment in the dark. Cells were collected by centrifugation $\left(2000 \times \mathrm{g}, 4^{\circ} \mathrm{C}, 5 \mathrm{~min}\right)$, washed, resuspended in PBS, and analysed as above reported.

\subsubsection{Measurement of Ceramide}

Level of ceramide was monitored by flow cytometry as follows. Briefly, $24 \mathrm{~h}$ after the treatment, $1.0 \times 10^{5}$ cells were incubated with $1 \mu \mathrm{g}$ of a mouse antihuman, ceramide monoclonal antibody (Alexis, Gruenberg, Germany) in PBS containing $0.1 \%$ bovine serum albumin (BSA) for $1 \mathrm{~h}$ at $37^{\circ} \mathrm{C}$. Cells were then washed twice with PBS-BSA and incubated for $30 \mathrm{~min}$ with $20 \mu \mathrm{L}$ of a goat anti-mouse, polyclonal, fluorescein isothiocyanate-conjugated, secondary antibody (Pharmingen, Germany) diluted 1/50 in PBS-BSA. Cells were then collected by centrifugation $\left(2000 \times g, 4{ }^{\circ} \mathrm{C}, 5 \mathrm{~min}\right)$, washed, resuspended in PBS, and analysed as above reported. 


\subsection{Haemolysis}

After $24 \mathrm{~h}$ treatment, a volume $(0.2 \mathrm{~mL})$ of the incubation mixture was diluted with 10 volumes of PBS and centrifuged at $1000 \times g$ for $10 \mathrm{~min}$ to precipitate the cells. The absorbance of the supernatant was then evaluated at $408 \mathrm{~nm}$ (DU-640 Spectrophotometer Beckman, Brea, CA, USA). Similarly, a volume of the incubation mixture was treated with 10 volumes of $5 \mathrm{mM}$ sodium phosphate buffer, pH 7.4 (hypotonic PBS), and briefly exposed to an ultrasonic bath. The absorbance value at $408 \mathrm{~nm}$ was taken as $100 \%$ haemolysis.

\subsection{Western Blotting}

RBCs were washed twice with PBS, resuspended in lysis buffer $(20 \mathrm{mM}$ Tris-HCl, pH 7.6, $100 \mathrm{mM}$ $\mathrm{NaCl}, 10 \mathrm{mM} \mathrm{MgCl}$, $2 \mathrm{mM}$ PMSF, $0.5 \mathrm{mM}$ DTT, and $2 \mathrm{mg} / \mathrm{mL}$ Lysozyme) with protease inhibitor cocktail (Roche Applied Science, Indianapolis, IN, USA), and sonicated for $60 \mathrm{~s}$ on ice with Labsonic LBS1-10 (Falc Instruments, Treviglio, Italy). After centrifugation at $40,000 \times \mathrm{g}$ for $1 \mathrm{~h}$ at $4{ }^{\circ} \mathrm{C}$, supernatant was collected. Protein concentration of each sample was determined by using Bradford protein assay reagent (Bio-Rad, Milan, Italy). Protein samples (50 $\mu \mathrm{g} /$ line) were separated on $10 \%$ SDS-PAGE and transferred to nitrocellulose membrane. Immunoblots were blocked overnight at $4{ }^{\circ} \mathrm{C}$ with $5 \%$ skimmed milk, followed by incubation with a 1:1000 dilution of mouse antihuman, caspase-3 monoclonal antibody (clone 3C119, Santa Cruz Biotechnology, Milan, Italy) for $1 \mathrm{~h}$ at room temperature. Blots were washed two times with Tween 20/Tris-buffered saline and incubated with a 1:2000 dilution of rabbit anti-mouse, horseradish peroxidase-conjugated anti-IgG antibody (Dako, Santa Clara, CA, USA) for $1 \mathrm{~h}$ at room temperature. Blots were then washed five times with Tween 20/Tris-buffered saline and then developed by enhanced chemiluminescence (Amersham Life Science, Milan, Italy).

\subsection{Scanning Electron Microscopy (SEM)}

SEM is a microscopic technique that does not use photons of light as optical microscopy but an electron beam that hits the sample. Thanks to the much lower electron wavelength, compared to the photon one, the resolution power of a scanning electron microscope is significantly higher than a visual display on an optical microscope. We are thus able to obtain images with magnification up to 20,000x, in which the details of the eryptotic erythrocytes are very evident. After $24 \mathrm{~h}$ of treatment, RBCs were prefixed for about $60 \mathrm{~min}$ in a $2 \%$ paraformaldehyde and $0.5 \%$ glutaraldehyde solution in Milloning buffer $\mathrm{pH}$ 7.3. The samples were then washed once in the same buffer and postfixed with $1 \%$ osmium tetraoxide in a Milloning buffer for two hours under stirring condition. Subsequently, the samples were washed again in a Milloning buffer and then dehydrated by an ascending ethanol scale $(30 \%, 50 \%, 70 \%$, $95 \%$, and 100\%): each step was repeated twice for $10 \mathrm{~min}$. After the last passage in $100 \%$ ethanol, the samples were treated with HMDS (hexamethyldisilazane) and left for $24 \mathrm{~h}$ in solution until complete evaporation. Finally, samples were grafted onto the supports for visualization by means of silver paste and subsequently metallized with gold and observed using a scanning electron microscope (JSM-6301F; JEOL Ltd., Japan). At each step, the samples were centrifuged at $1000 \times g$ to create a cell pellet.

\subsection{Glutathione Measurements}

Intracellular GSH/GSSG levels were measured by employing a glutathione colorimetric assay kit according to manufacturer's instruction (Invitrogen, Milan, Italy).

\section{7. $P G E_{2}$ Measurements}

After incubation, as indicated above, $\mathrm{PGE}_{2}$ released $\left(\mathrm{pg} / 1 \times 10^{8}\right.$ cells) was quantified using a $\mathrm{PGE}_{2}$ Enzyme Immunoassay Kit (Cayman Chemical Corporation Inc., Milan, Italy) in accordance with the manufacturer's protocol. Briefly, after treatment, cells were pelleted by centrifugation at $4{ }^{\circ} \mathrm{C}$, for $5 \mathrm{~min}$ at $450 \times$ g. Samples of the supernatant were diluted at 1:2.5 with assay buffer. Then, a $100 \mu \mathrm{L}$ sample, a $50 \mu \mathrm{L}$ alkaline phosphatase $\mathrm{PGE}_{2}$ conjugate, and a $50 \mu \mathrm{L}$ monoclonal anti-PGE 2 EIA antibody were 
applied to a goat anti-mouse IgG-containing microtiter plate and incubated at room temperature for $2 \mathrm{~h}$. After washing, $200 \mu \mathrm{L}$ of $p$-nitrophenyl phosphate substrate solution was added and incubated at room temperature for $45 \mathrm{~min}$. Finally, optical density at $405 \mathrm{~nm}$ was measured on a microplate reader. $\mathrm{PGE}_{2}$ concentrations in the samples were calculated from a PGE 2 standard curve $(25-5000 \mathrm{pg} / \mathrm{mL})$ that was run in parallel.

\subsection{Endothelial Cell Culture}

\subsubsection{Adherence Assay of Eryptotic Rbcs}

Human Umbilical Vein ECs (HUVEC) were purchased from PromoCell, Milan, Italy and used for up to four additional passages. Cells were grown in $75-\mathrm{cm}^{2}$ flasks with endothelial cell basal medium MV2 (PromoCell) containing $100 \mathrm{pg} / \mathrm{mL}$ of heparin, 10\% foetal bovine serum (GIBCO), 120 U/mL penicillin/streptomycin, and $30 \mathrm{pg} / \mathrm{mL}$ of endothelial cell growth supplement. At 85\% confluence, cells were subcultured in 96-well, flat-bottom plates. Cellular monolayers were co-incubated with HNE-stimulated RBCs ( 25 or $50 \mu \mathrm{M}$ ) or control RBCs for $48 \mathrm{~h}$. After treatment, the adherence of RBCs to HUVEC was measured by the gravity adherence assay as previously reported [23].

\subsubsection{Measurements of ICAM-1 Expression}

After $24 \mathrm{~h}$ co-incubation with RBCs, HUVECs were washed with phosphate buffered saline (PBS), harvested with cell dissociation medium, and diluted in a washing buffer containing $0.1 \%$ bovine serum albumin and $1 \mathrm{mM} \mathrm{CaCl}_{2}$. Aliquots $\left(0.1\right.$ to $0.5 \times 10^{6}$ cells in $\left.20 \mu \mathrm{L}\right)$ were incubated at $4{ }^{\circ} \mathrm{C}$ with $2 \mu \mathrm{g} /$ well of a mouse antihuman ICAM-1 monoclonal antibody FITC-conjugated (Invitrogen, Milan, Italy). After $1 \mathrm{~h}$ at $4{ }^{\circ} \mathrm{C}$, cells were washed and analysed by FACS.

\subsection{Statistical Analysis}

Results are expressed as mean \pm SD of six independent experiments and conducted in triplicates. Statistical comparisons were performed by one-way analysis of variance (ANOVA) followed by Fisher's correction for multiple comparisons using Prism version 8 (GraphPad Software Inc., San Diego, USA). In all cases, significance was accepted if the null hypothesis was rejected at the $p<0.05$ level.

\section{Results and Discussion}

\subsection{HNE Induces PS Externalization in Human RBCs}

HNE, instead of a mere by-product of oxidative stress, is capable of modifying nucleophilic residues and, depending on its concentration, can either orchestrate cell signalling events or modify target proteins, thus dysregulating functional cellular processes such as proliferation and apoptosis [10,20,24-32]. In this paper, we focused on the HNE ability to modulate proapoptotic pathways and evaluated its eventual proeryptotic effects in a concentration range of pathophysiological relevance. As an initial approach toward this aim, HNE-induced PS externalized was assessed by incubating RBCs for $24 \mathrm{~h}$ in the absence (control) or in the presence of the aldehyde in the range between 10 and $100 \mu \mathrm{M}$. When compared to control cells, stimulation with HNE resulted in a significant, concentration-dependent increase of PS externalized expressed as \% of Annexing V-binding cells. Indeed, the value progressively raised from $3.4 \% \pm 0.2 \%$ with control cells to $61 \% \pm 3 \%$ with $100 \mu \mathrm{M}$ HNE ( $p<0.05$, Figure 1A,B). Successive experiments were, then, conducted with HNE between 25 and $50 \mu \mathrm{M}$, a concentration range frequently found in the plasma of obese subjects and patients affected by cardiometabolic and inflammatory pathologies [1-4]. Moreover, both in vitro and ex vivo evidences have reported that HNE concentrations close to $50 \mu \mathrm{M}$ induce insulin resistance in muscle cells, in isolated skeletal muscle, and in adipocytes [14,33,34]. 


\subsection{HNE Induces a Low Grade of Haemolysis in Human RBCs}

In order to determine whether the HNE-mediated eryptosis was also associated to necrotic events, we next evaluated if and to what extent the aldehyde was able to induce haemolysis. To this end, RBCs were incubated for $24 \mathrm{~h}$ in the absence (control) or in the presence of HNE in the range between 25 and $50 \mu \mathrm{M}$ and $\mathrm{Hb}$ release was measured. With respect to control cells, HNE induced a significant increase of haemoglobin release only at $50 \mu \mathrm{M}$ with a value increasing from $3.8 \% \pm 0.3 \%$ to $7.6 \% \pm$ $0.4 \%(p<0.05$, Figure 1C).
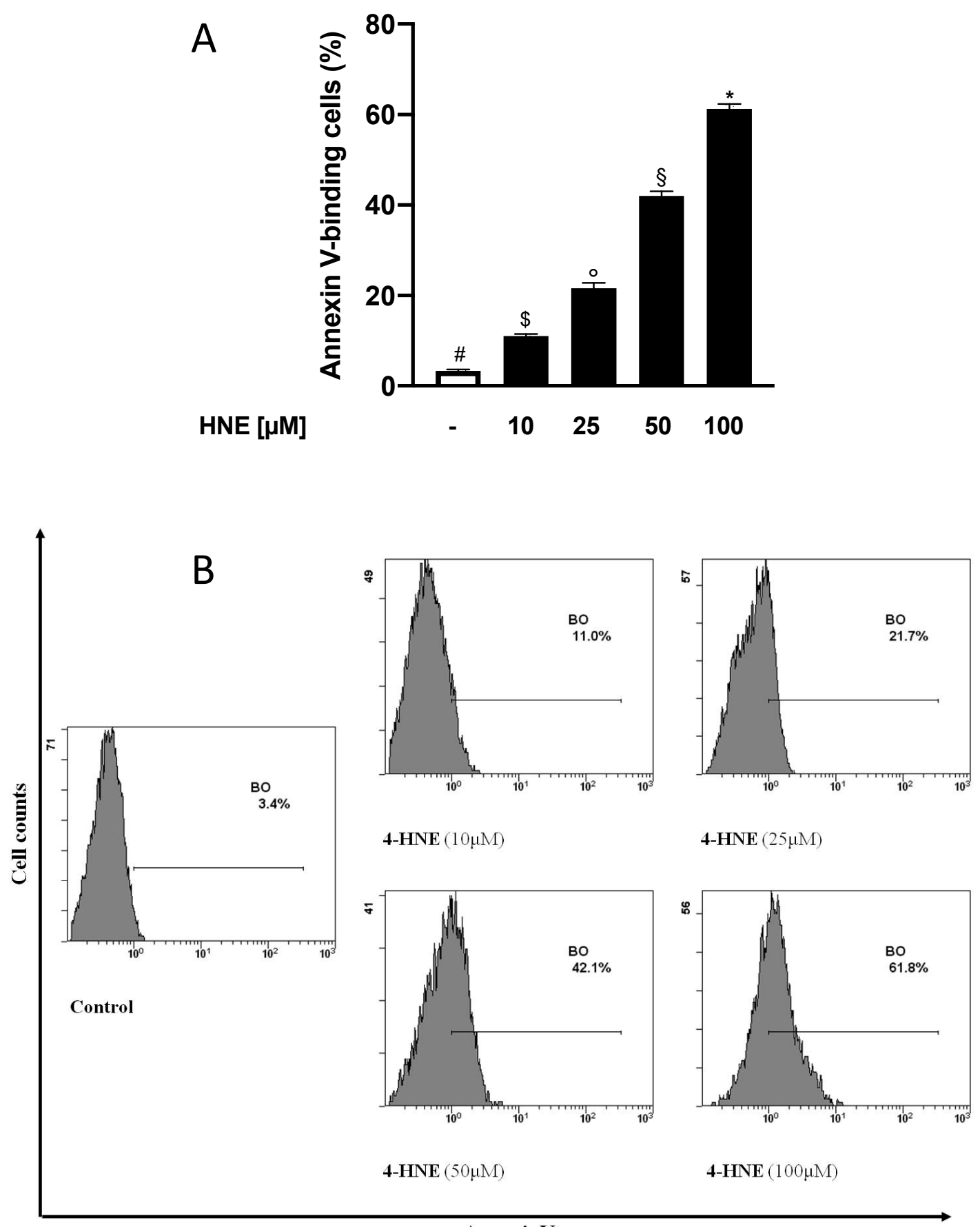

AnnexinV

Figure 1. Cont. 


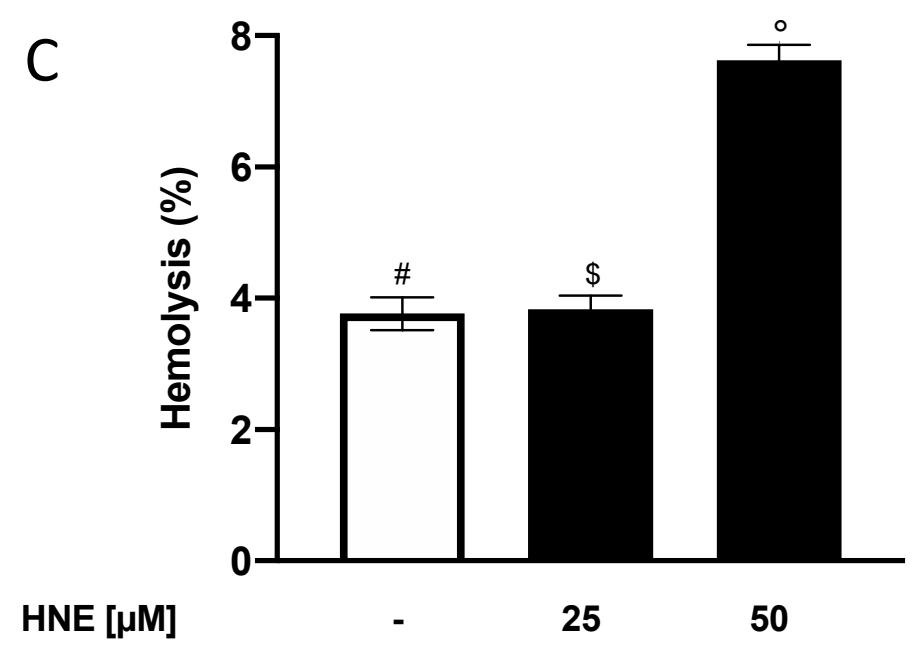

Figure 1. (A) Percentage of Annexin V-binding in 4-Hydroxy-trans-2-nonenal (HNE)-treated erythrocytes (RBCs). (B) Histogram of the \% Annexin-V binding cells in a typical experiment: RBCs incubated with vehicle were used as control; images representative of six experiments were carried out in triplicate with comparable results. (C) Haemolysis in HNE-treated RBCs. For both Figure 1A,C, values are means \pm SD of six independent experiments carried out in triplicate. Bars with special characters are significantly different with $p<0.05$ (ANOVA associated with Fisher's correction).

When compared to the percentage of eryptotic cells, these values demonstrate that, in the process underlying HNE-induced RBC death, eryptotic mechanisms dominated over the necrotic ones. These results are also in line with those reported from our research group with other lipidic, proeryptotic stimuli such as oxysterols with which HNE seems to share the ability to stimulate predominantly eryptotic events [35]. Interestingly, present findings could also imply that, in vivo, HNE at physiopathological concentrations could eventually injure erythrocytes to an extent far from significantly inducing intravascular haemolysis and its detrimental clinical sequelae (gastrointestinal, cardiovascular, pulmonary, urogenital, and clotting disorders) [1,36,37].

\subsection{HNE Induces Morphological Changes in Human RBCs}

As before-mentioned, eryptosis is well known to induce evident morphological variations characterised by cell volume reduction and membrane blebbing. With the aim to investigate and characterise the HNE-induced morphological alterations in RBCs, we assessed FSC variations and performed scanning electron microscopy evaluations in both control and HNE-treated RBCs. As shown in Figure 2A, HNE determined a significant increase of FSC with respect to control cells with values increasing from $542 \pm 2$ Relative Units (RU) with untreated cells to $575 \pm 3$ and $600 \pm 2$ RU with 25 and $50 \mu \mathrm{M}$ HNE respectively $(p<0.05)$. Our results suggest that HNE-induced eryptosis is accompanied with an apparent increase of RBC volume and differs from those reported in literature for other eryptotic models. It has indeed been demonstrated that RBCs, either stimulated with other eryptotic agents or isolated from patients suffering from sepsis or cardiometabolic or blood disorders, are characterised by a reduction of cell volume $[1,4,6]$.

In order to further investigate these discrepancies, we next employed a SEM approach and analysed the morphological alteration in eryptotic RBCs. Figure 2 shows the onset after treatment with HNE for $24 \mathrm{~h}$ (Figure 2C,D) of altered cell morphologies not detectable in untreated samples (Figure 2B). Control RBCs have a shape and size comparable to the standards described in literature [38]. The acanthocytes (green arrow) appear characterized by a few irregular spicules with a blunt tip. These changes in their morphology are irreversible, while the echinocytes (red arrow), called porcupine cells or burr cells, show numerous narrow-tipped spicules regularly distributed on the surface of the red cell membrane. The latter alterations are instead considered reversible. The presence of numerous 
and irregular blebbing on the surface of eryptotic RBCs agrees with the apparent increase in volume detected by FSC and would exclude an actual increase of cellular volume.

\section{A}

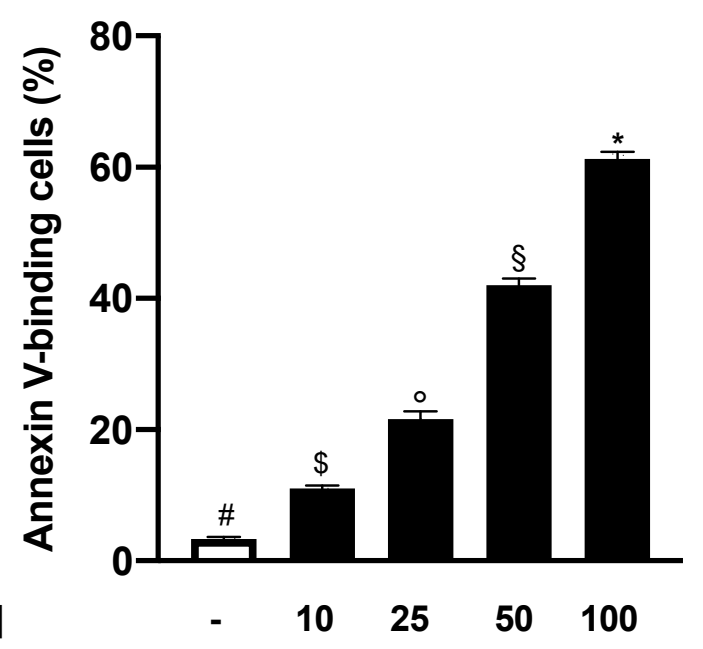

HNE $[\mu \mathrm{M}]$

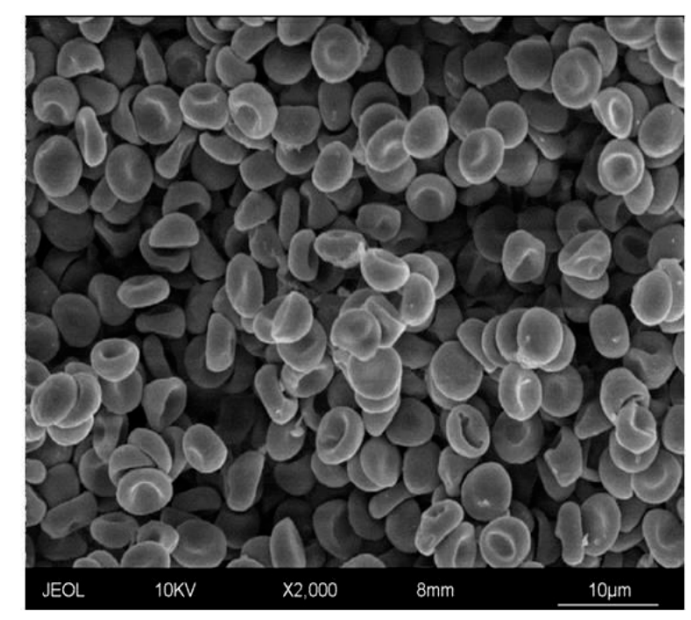

B

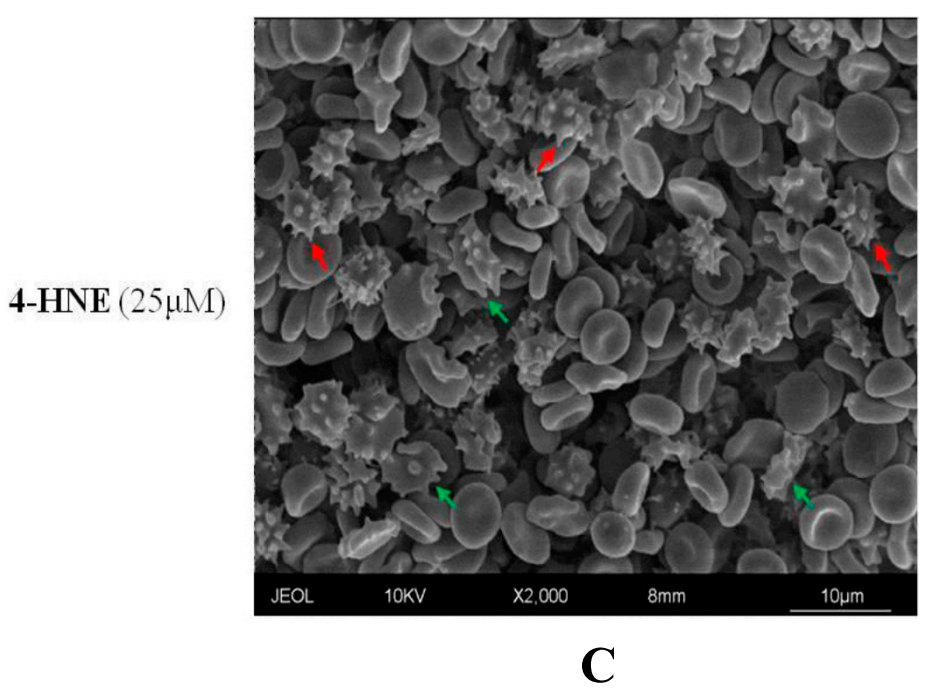

Figure 2. Cont. 


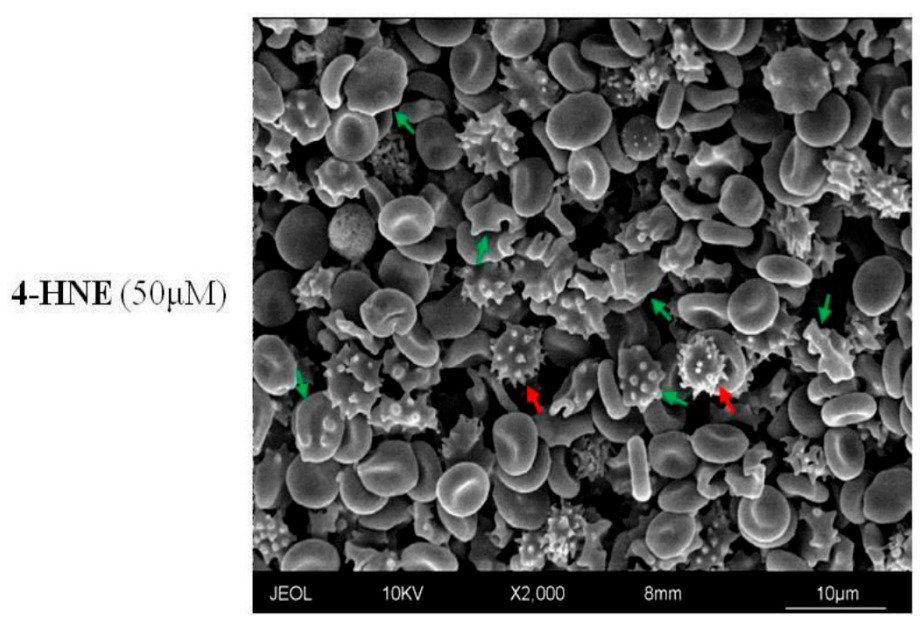

D

Figure 2. (A) FCS of HNE-treated RBCs: Values are means \pm SD of six independent experiments carried out in triplicate. Bars with special characters are significantly different with $p<0.05$ (ANOVA associated with Fisher's correction). SEM surveys of control RBC (B) or HNE-treated RBCs (C,D). Acanthocytes and echinocytes are identified by green and red arrows, respectively. Images are representative of six independent experiments carried out in triplicate.

By analyzing in details the complex cytological framework, primary echinocytes and polyhedrocytes were detected and identified (Figure 3B,C). These cellular forms are characteristic of an early eryptotic phase, during which the PS exposure process begins. Furthermore, the presence of agglutinated elements, with partial fusion of cell membranes, is of considerable interest (Figure 3D, fusion elements are indicated by the yellow arrows). These agglutination elements, through the interaction with other elements like platelets or ECs, can indeed sustain thrombotic and inflammatory processes usually associated to circulating eryptotic RBCs. From a mechanistic perspective, the different morphological changes found through SEM analysis could derive from the rearrangement of the membrane and cytoskeleton proteins [39]. In this regard, it is worthwhile to underline that HNE can accumulate in erythrocytic plasma membrane, can perturbate membrane fluidity, and can form protein adducts with spectrin and other membrane and cytoskeleton proteins in a variety of pathophysiological conditions (diabetes, renal disease, glucose-6-phosphate dehydrogenase deficiency, sickle cell anaemia, and tropical diseases) [40-42].

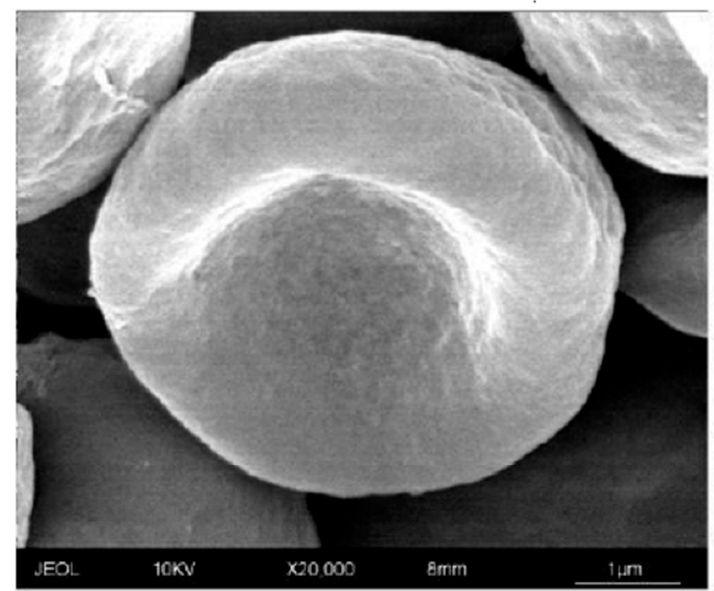

A

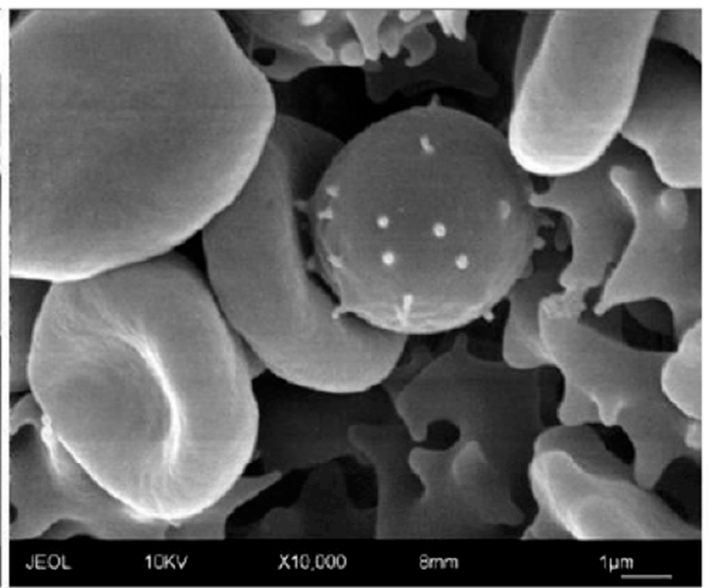

B

Figure 3. Cont. 


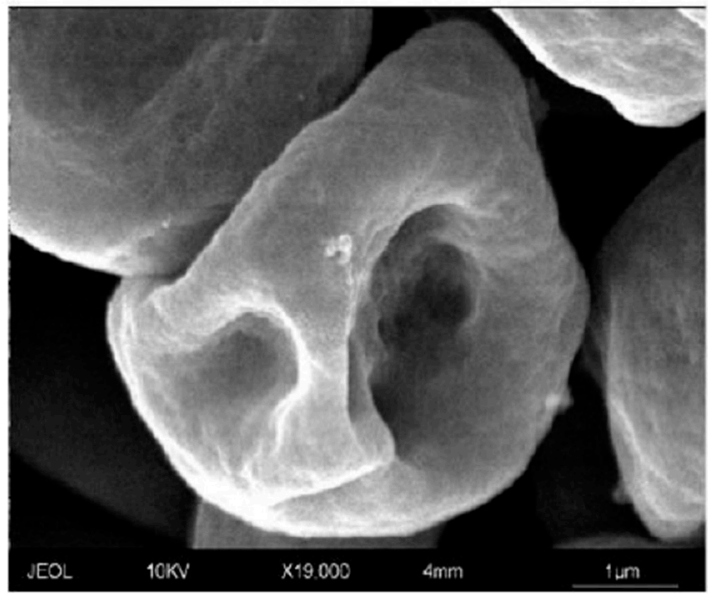

C

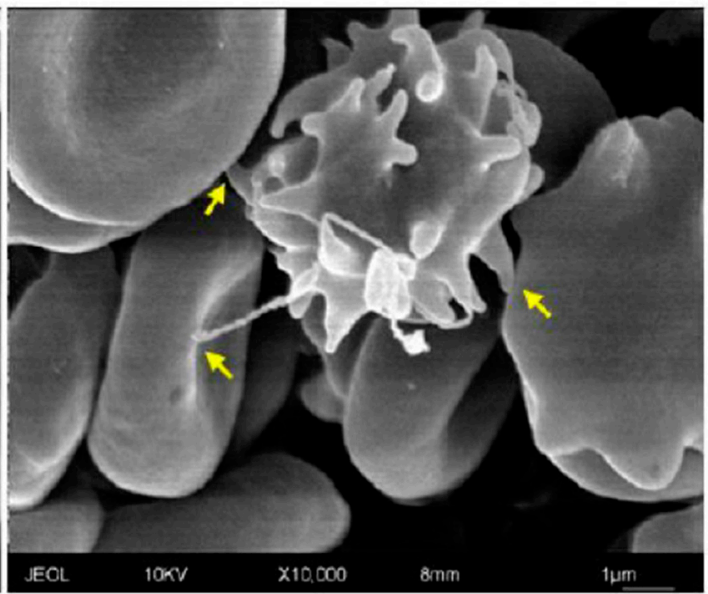

D

Figure 3. SEM analysis of control RBC (A), primary echinocyte (B), polyhedrocyte (C), and agglutination between eryptotic RBCs with fusion elements indicated by the yellow arrows (see text) (D): Images are representative of six independent experiments carried out in triplicate.

\subsection{HNE Induces Cleavage of Procaspase 3 in Human RBCs}

Notwithstanding that RBC is devoid of nucleus, mitochondria, and other organelles, it does have a molecular machinery, saved during the differentiation from erythroid progenitors, with functional caspases. Activation of these effectors is a key step in the eryptosis induced by either specific xenobiotic or physiopathological conditions [3,5,6,43]. Indeed, caspases often mediate eryptosis-triggered morphological modifications by degrading crucial proteins involved in the maintenance of erythrocyte's shape and function, ultimately leading to an accelerated cell removal from circulation [39,44-46].

In light of the morphological changes triggered by HNE in eryptotic RBCs, we next evaluated the involvement of caspase-3 in the HNE-induced eryptosis. To this end, RBCs were incubated for $24 \mathrm{~h}$ in the absence (control) or in the presence of HNE in the range between 25 and $50 \mu \mathrm{M}$ and caspase- 3 cleavage was evaluated. With respect to control RBCs, stimulation with HNE at 25 and $50 \mu \mathrm{M}$ significantly modified caspase- 3 levels that increased from a control value of $0.12 \pm 0.01$ Arbitrary Units (AU) to $1.45 \pm 0.2$ and $1.73 \pm 0.1 \mathrm{AU}$ respectively. Conversely, procaspase- 3 levels decreased from $1.13 \pm 0.04$ AU to $0.94 \pm 0.05$ and $0.70 \pm 0.05 \mathrm{AU}(p<0.05$, Figure 4$)$.

These results are coherent with those previously reported from other groups, showing that caspase 3 is the principal mediator of HNE-mediated RBC damage during arsenic exposure [25] and is involved in the HNE-induced cell apoptosis in Jurkat cells [26].

$\mathbf{A}$

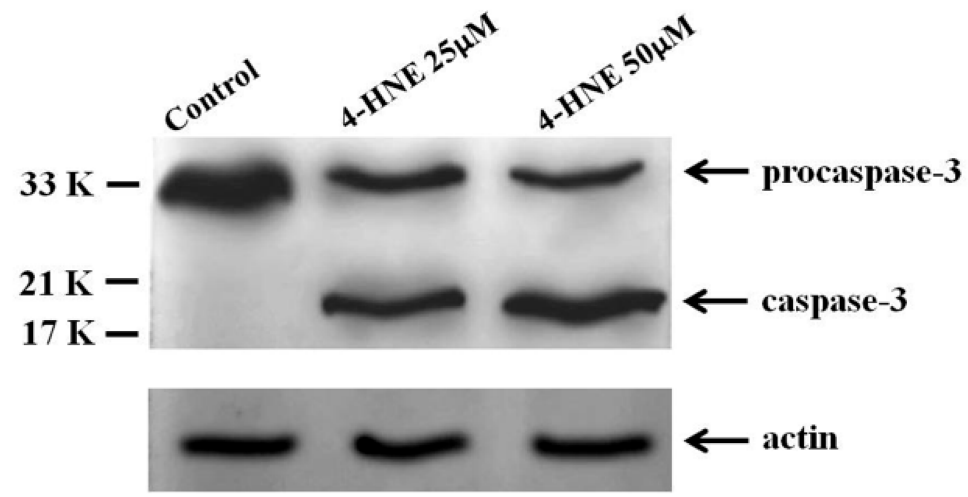

Figure 4. Cont. 

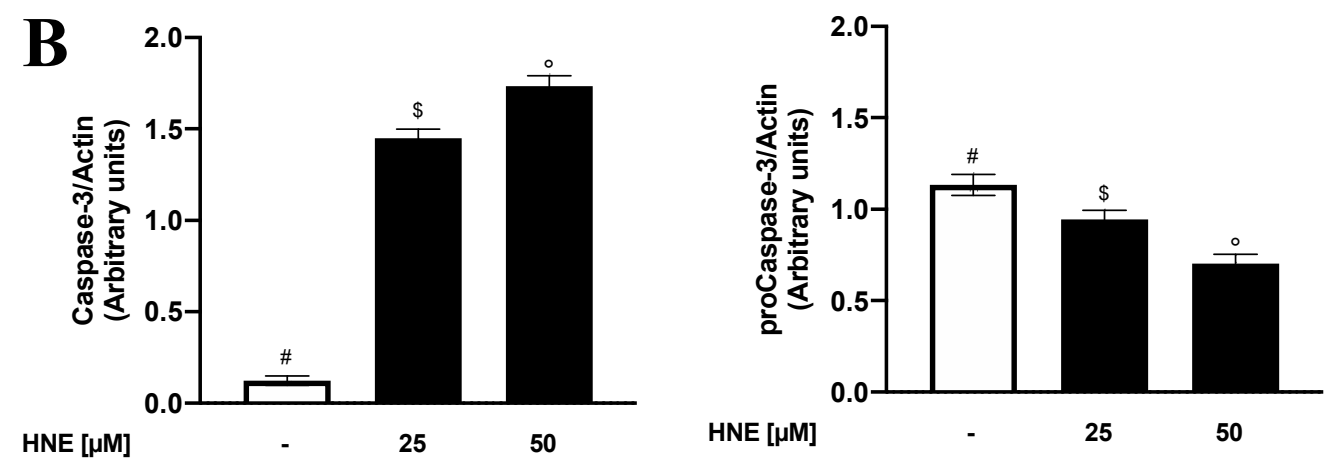

Figure 4. (A) Western blot analysis of procaspase-3 and caspase-3 in HNE-treated RBCs: Image is representative of three independent experiments. (B) Densitometric analysis of procaspase-3 and caspase- 3 levels normalized for actin in the same condition as in Figure 4A. Values are means \pm SD of three independent experiments. Bars with special characters are significantly different with $p<0.05$ (ANOVA associated with Fisher's correction).

\subsection{Intracellular $\mathrm{Ca}^{++}$Variations Are Involved in the HNE-Induced Eryptosis in Human Rbcs}

As abovementioned, a wealth of studies confirmed a strict correlation between $\mathrm{Ca}^{++}$increase and the activation of signalling processes that ultimately lead to activation of erythrocyte scramblase responsible for PS externalization $[1,4,6]$. In order to gain deeper insights on the mechanisms responsible for the HNE-induced eryptosis, we next evaluated the involvement of $\mathrm{Ca}^{++}$in PS externalization. To this end, RBCs were incubated for $24 \mathrm{~h}$ in the absence (control) or in the presence of HNE in the range between 25 and $50 \mu \mathrm{M}$ and $\mathrm{Ca}^{++}$endocellular levels were evaluated and expressed as \% of positive cells. As shown in Figure 5, HNE determined an increase of intracellular $\mathrm{Ca}^{++}$with values rising from a control value of $1.8 \% \pm 0.2 \%$ to $20.5 \% \pm 0.4 \%$ and $41.5 \% \pm 0.4 \%$ with 25 and $50 \mu \mathrm{M} \mathrm{HNE}$, respectively $(p<0.05)$.
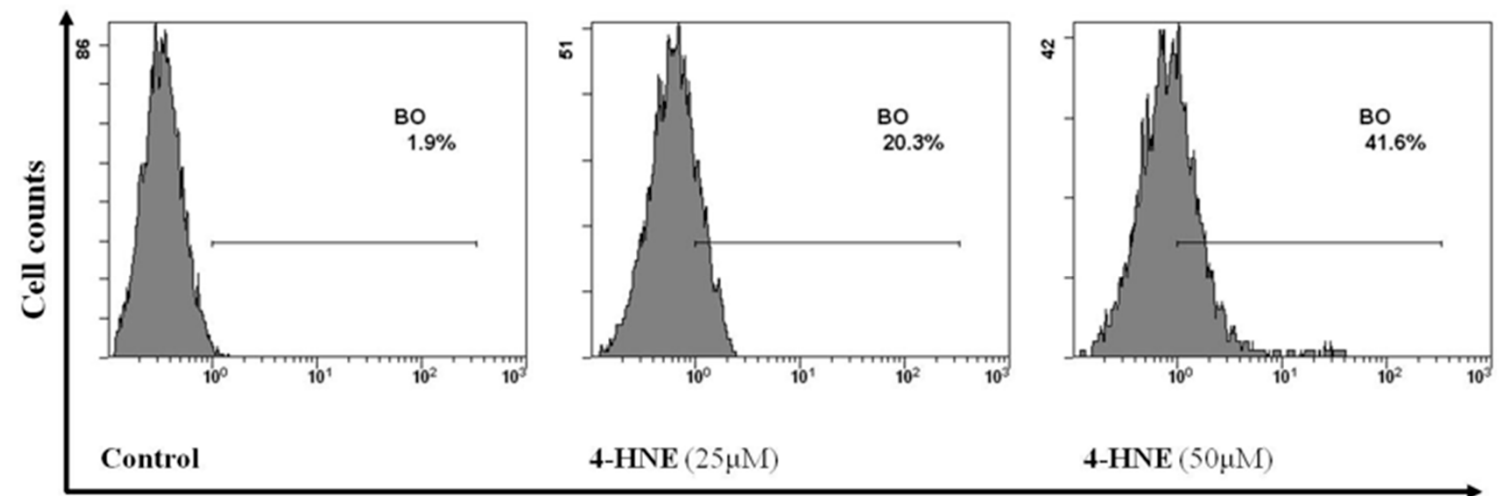

Fluo-3 AM

Figure 5. Flow cytometry analysis of $\mathrm{Ca}^{++}$positive cells in HNE-treated RBCs: Image is representative of six independent experiments carried out in triplicate.

To confirm the role of $\mathrm{Ca}^{++}$in the eryptotic process, $\mathrm{RBC}$ s were incubated with HNE either in the absence or in the presence of $\mathrm{Ca}^{++}$and PS externalization was evaluated. As expected, absence of $\mathrm{Ca}^{++}$resulted in a significant reduction of PS externalization, induced by HNE at 25 or $50 \mu \mathrm{M}$, by $68 \% \pm 1 \%$ and $72 \% \pm 1 \%$ respectively $(p<0.05$, Figure 6$)$. 
A

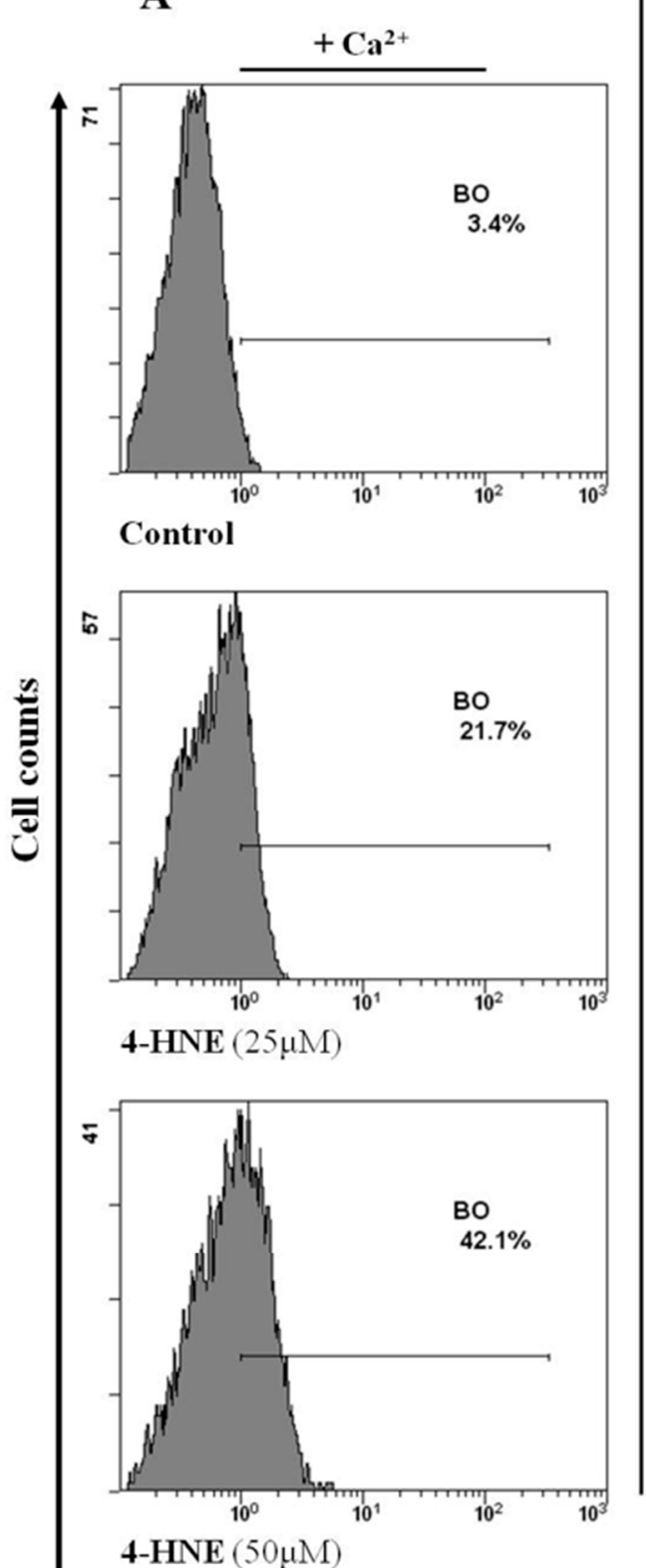

B

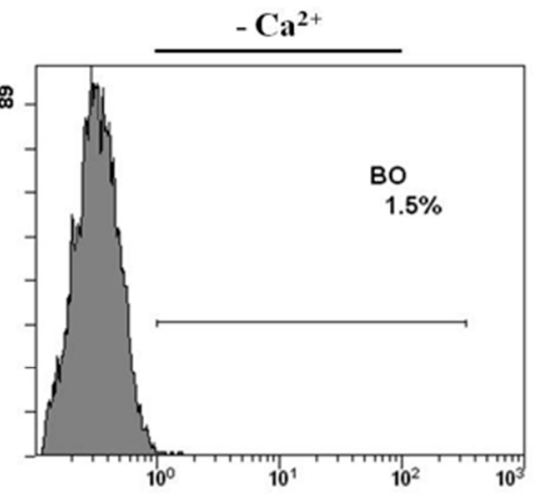

Control

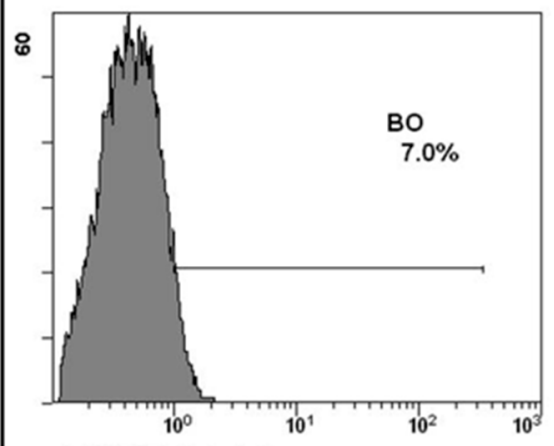

4-HNE $(25 \mu \mathrm{M})$

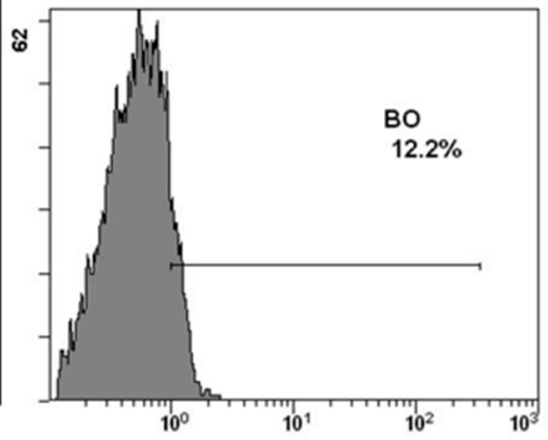

4-HNE $(50 \mu \mathrm{M})$

\section{AnnexinV}

Figure 6. Flow cytometry analysis of Annexin-V binding cells either in the presence (A) or in the absence $(\mathbf{B})$ of $\mathrm{Ca}^{++}$in a typical experiment with HNE-treated RBCs. Image is representative of six independent experiments carried out in triplicate.

As a whole, these results demonstrate that the HNE-induced eryptosis is mediated by a disruption of $\mathrm{Ca}^{++}$homeostasis and are in line with current literature that gives to $\mathrm{Ca}^{++}$a key role in the eryptotic process $[1,2,4,37,47]$. The mechanism responsible for the increased $\mathrm{Ca}^{2+}$ levels might well be related to the opening of $\mathrm{Ca}^{2+}$-permeable NSCM channels as it happens with other already-known proeryptotic stimuli [3]. While the molecular identity of these transporters remains elusive, they might partially involve the transient receptor potential channel TRPC6. The lack of TRPC6, however, does not completely abrogate $\mathrm{Ca}^{2+}$ entry, suggesting that further cation channels are operating in erythrocytes. The structure of those channels remains to be established [48]. Finally, consistent with our findings, other reports described $\mathrm{Ca}^{++}$as one the signalling tools that $\mathrm{HNE}$ uses to exert both its pathophysiological and proapoptotic effects $[10,19,20,27,49]$. 


\subsection{Endocellular Redox Variations Are Not Involved in the HNE-Induced Eryptosis in Human RBCs}

RBCs are considered "reporter cells" for the oxidative state since they can be particularly vulnerable to RONS due to their constant exposure to by-products generated by autoxidation of haemoglobin [50]. Moreover, oxidative stress has been associated in phospholipid remodeling and cell dysfunction in a number of eryptotic processes associated with several clinical conditions such as heart failure, diabetes, anaemia, and chronic inflammatory diseases [2-6]. Oxidative stress is, indeed, effective at least in part by activating $\mathrm{Ca}^{2+}$-permeable NSCM channels and by initiating a series of events ultimately leading to cell shrinkage and PS externalization [51]. In light of our present results underlying the key role exerted by $\mathrm{Ca}^{2+}$ in our experimental system, we next evaluated the involvement of oxidative stress in HNE-induced eryptosis. To this end, RBCs were incubated for $24 \mathrm{~h}$ in the absence (control) or in the presence of HNE between 25 and $50 \mu \mathrm{M}$ and both endocellular RONS and GSH/GSSG levels evaluated. As shown in Figure 7, HNE did not induce any variation of intracellular levels of both RONS and GSH/GSSG at all the concentration tested.
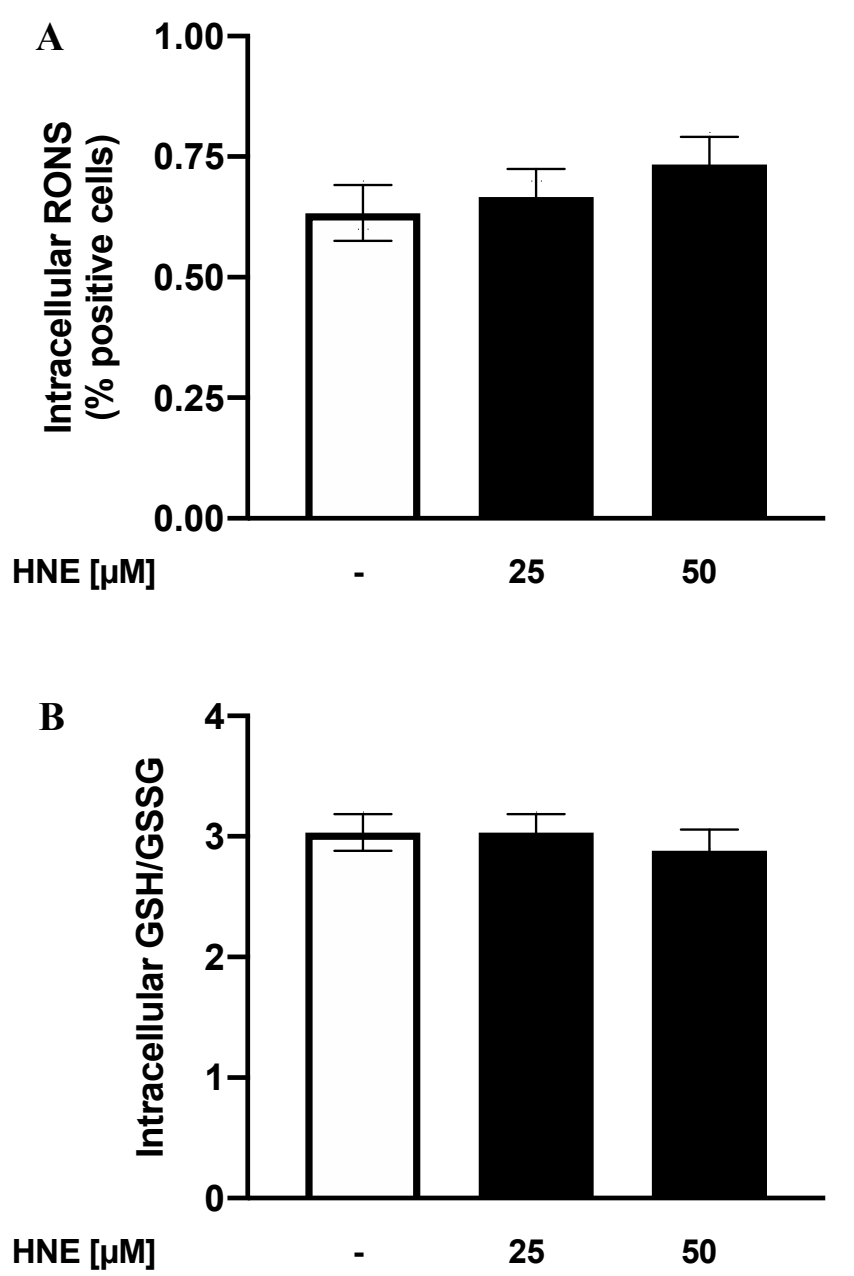

Figure 7. Analysis of Reactive Oxygen and Nitrogen Species (RONS) positive cells (A) and intracellular GSH/GSSG levels (B) in HNE-treated RBCs: Values are means \pm SD of six independent experiments carried out in triplicate ( $p>0.05$, ANOVA associated with Fisher's correction).

Notwithstanding the role of oxidative stress in eryptosis induced by other agents $[1,3,52]$ and in the HNE-induced apoptosis or cytotoxicity $[20,26,53]$, our results rule out that significant endocellular redox modifications are involved in the $\mathrm{Ca}^{++}$-dependent, $\mathrm{HNE}$-induced eryptosis. Other mechanisms, related to NSCM activation, could therefore underlie the process. 


\subsection{PGHS Activation and PGE 2 Levels Are Involved in the HNE-Induced Eryptosis in Human RBCs}

PGHS and $\mathrm{PGE}_{2}$ are deeply involved in the eryptotic signalling induced by several stimuli, through the opening of NSCM channels that leads to an increase of cytosolic $\mathrm{Ca}^{++}$levels. Along these lines, we therefore evaluated whether the $\mathrm{Ca}^{++}$influx in HNE-treated RBCs was dependent by activation of PGHS. To this end, RBCs were preincubated either in the absence or in the presence of $50 \mu \mathrm{M}$ ASA and stimulated with HNE in the range between 25 and $50 \mu \mathrm{M}$, and then, both endocellular $\mathrm{Ca}^{++}$levels and PS externalization were evaluated. As shown in Figure 8, with respect to RBCs stimulated with HNE at 25 and $50 \mu \mathrm{M}$, pretreatment with ASA resulted in a reduction of PS externalization by $55 \% \pm 1 \%$ and by $68 \% \pm 2 \%$, respectively; similarly, $\mathrm{Ca}^{++}$release was reduced by $-71 \% \pm 2 \%$ and $-69 \% \pm 1 \%$, respectively.

In light of these results, we then assessed the effects of $\mathrm{HNE}$ on $\mathrm{PGE}_{2}$ production. To this end, $\mathrm{RBC}$ were incubated for $24 \mathrm{~h}$ in the absence (control) or in the presence of HNE in the range between 25 and $50 \mu \mathrm{M}$ and $\mathrm{PGE}_{2}$ release was evaluated. When compared to control cells, treatment of RBCs with $\mathrm{HNE}$ significantly modified endocellular $\mathrm{PGE}_{2}$ levels that increased from a control value of $5.1 \pm$ 0.1 to $10.1 \pm 0.3$ and $14.6 \pm 0.3 \mathrm{pg} / 10^{8} \mathrm{RBC}$ s with 25 and $50 \mu \mathrm{M} \mathrm{HNE}$, respectively $(p<0.05$, Figure 9).

As a whole, these results demonstrate that the HNE-induced eryptosis is mediated by PGHS activation (essential to rise of $\mathrm{Ca}^{++}$levels and PS externalization) and accompanied by the resulting increase of $\mathrm{PGE}_{2}$ levels. While ruling out a direct interaction of HNE with NSCM channels, our data also implied an HNE-induced synthesis of $\mathrm{PGE}_{2}$ in the RBCs. The aldehyde, therefore, seems to share with other proeryptotic stimuli a common $\mathrm{PGE}_{2}$-dependent mechanism to promote an increase of $\mathrm{Ca}^{++}$ levels $[1,3,4,54]$. Finally, focusing on the HNE-induced PGHS modulation, it is worth to underline that aldehyde has widely been reported to modulate AA metabolism by upregulating COX-2 protein levels in numerous experimental systems relevant to several diseases (atherosclerosis, osteoarthritis, obesity, and inflammation) [55-59]. Our results, obtained in the anucleate RBCs, indicate for HNE a further mechanism through which the aldehyde can stimulate AA metabolism that proceeds via PGHS activation rather than via its upregulation.

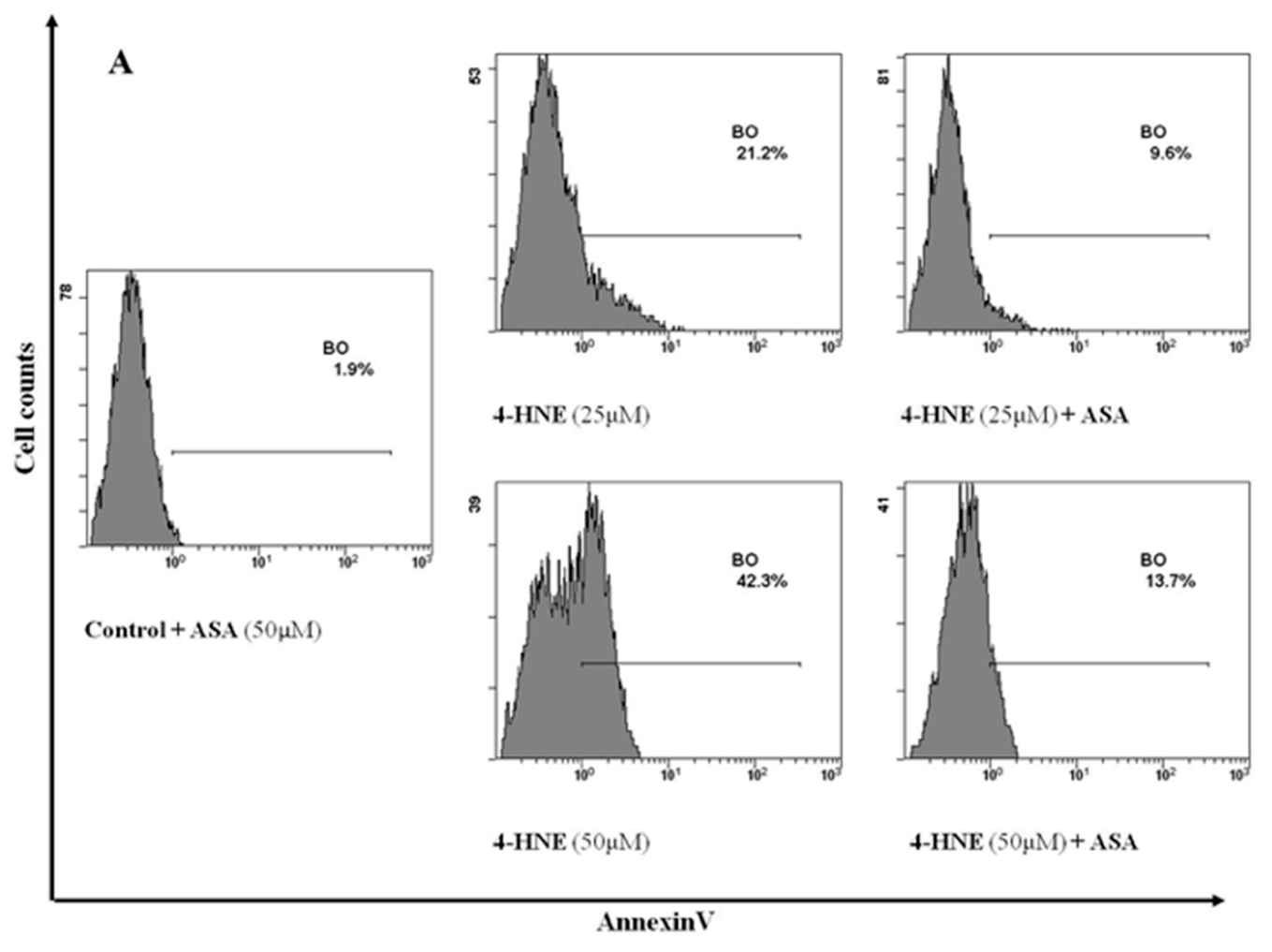

Figure 8. Cont. 


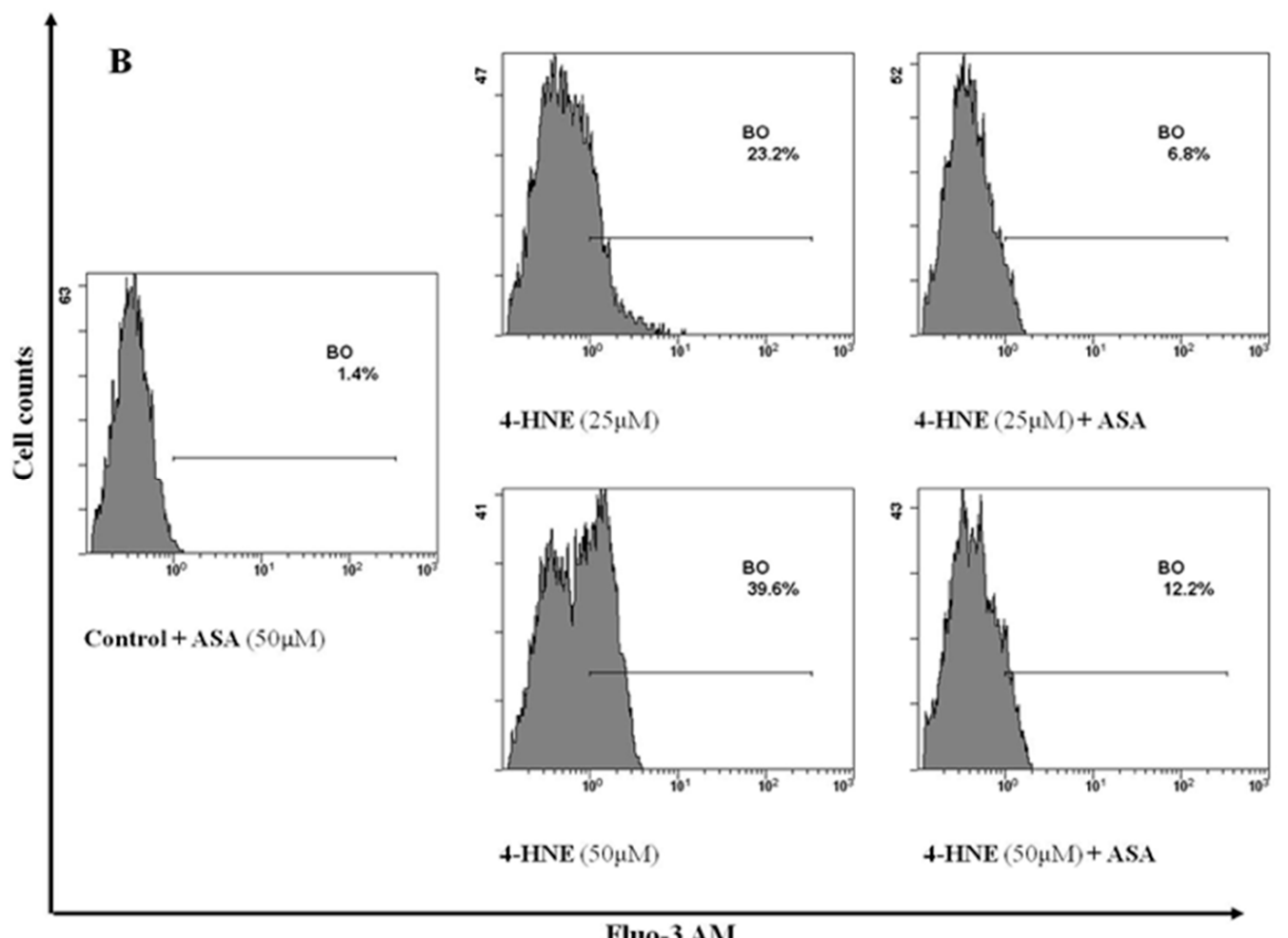

Fluo-3 AM

Figure 8. Flow cytometry analysis of Annexin- $\mathrm{V}$ binding cells (A) and $\mathrm{Ca}^{++}$positive cells $(\mathbf{B})$ in $\mathrm{RBCs}$ preincubated in the absence or in the presence of $50 \mu \mathrm{M}$ ASA and then stimulated with HNE in the range between 25 and $50 \mu \mathrm{M}$ for $24 \mathrm{~h}$ : Image is representative of six independent experiments carried out in triplicate.

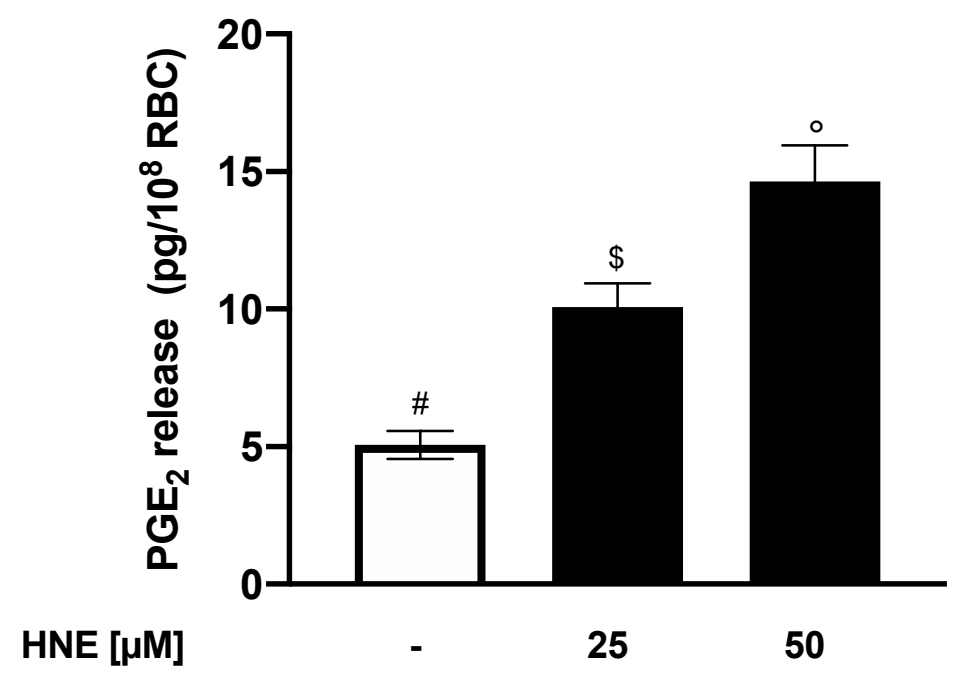

Figure 9. $\mathrm{PGE}_{2}$ release from HNE-treated RBCs: Values are means $\pm \mathrm{SD}$ of six independent experiments carried out in triplicate. Bars with special characters are significantly different with $p<0.05$ (ANOVA associated with Fisher's correction).

3.8. Increased Levels of Endocellular Ceramide Are Involved in the HNE-Induced Eryptosis in Human RBCS

Lang at al. proved that two signalling pathways converge to trigger eryptosis. In the first one, $\mathrm{PLA}_{2}$ activation produces $\mathrm{AA}$, which then transforms into $\mathrm{PGE}_{2}$ that stimulates the entrance of $\mathrm{Ca}^{++}$ into the cell [54]. In the second pathway, $\mathrm{PLA}_{2}$ activation also produces a liso-derivate which transforms into PAF that activates SMase. This latter ends up promoting PS externalization and eryptosis by 
generating ceramides [47]. Along these lines, several xenobiotics and numerous proeryptotic conditions (hyperosmotic shock, fever, sepsis, HUS, uraemia, hepatic failure, and Wilson's disease) have been reported to stimulate eryptosis at least in part by increasing ceramide abundance [52,60].

Along these lines, having observed the key role of $\mathrm{Ca}^{++}$in our experimental system, we then focused on the second mechanism and evaluated the involvement of ceramide in the HNE-induced eryptosis. To this end, RBCs were incubated for $24 \mathrm{~h}$ in the absence (control) or in the presence of HNE in the range between 25 and $50 \mu \mathrm{M}$ and then ceramide levels were assessed as \% positive cells. Interestingly, treatment of RBCs with HNE significantly modified the percentage of RBCs containing ceramide that increased from a control value of $5.4 \pm 0.1$ to $20.5 \pm 0.3$ and $44.3 \pm 0.3$ with 25 and $50 \mu \mathrm{M}$ HNE respectively $(p<0.05$, Figure 10).
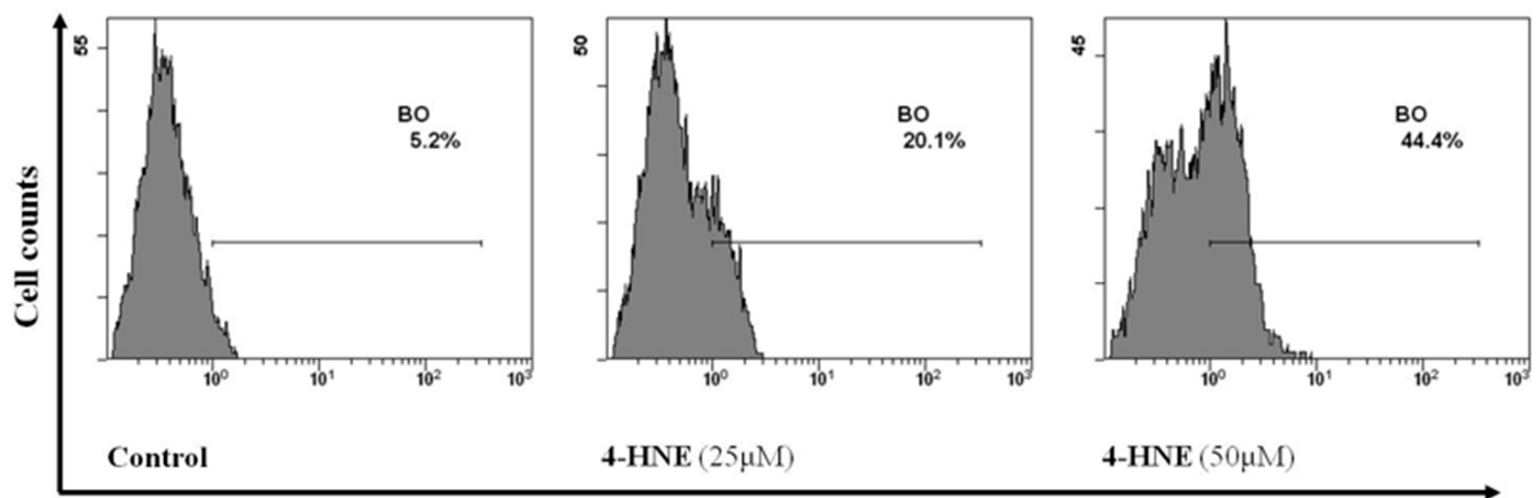

anti-Ceramide FITC

Figure 10. Flow cytometry analysis of ceramide positive cells in HNE-treated RBCs: Image is representative of six independent experiments carried out in triplicate.

As a whole, our results demonstrate that HNE at physiopathological concentrations induces eryptosis by generating an increase of both $\mathrm{PGE}_{2}$ and ceramide. Along these lines, both these signals, produced as consequence of $\mathrm{PLA}_{2}$ activation, might result from an $\mathrm{HNE}$-induced alteration of membrane structure.

\subsection{HNE-Induced Eryptosis in Human RBCs is Associated with Endothelial Cell Adhesion and Dysfunction}

Physiological PS externalization is crucial for injured RBCs to be cleared up by macrophages and to prevent premature haemolysis and the following release of haemoglobin in the circulation. On the other hand, through PS exposure, eryptotic RBCs can adhere to ECs and can severely dysfunctionate vascular wall in several pathological conditions such as sickle cell anaemia, malaria infections, diabetes, polycythaemia vera, and retinal vein occlusion $[6,61,62]$.

In line with this, we finally investigated to what extent HNE-induced eryptosis would increase RBC adherence to ECs. To this end, confluent HUVEC were co-cultured for $48 \mathrm{~h}$ either with control RBCs or with HNE-stimulated RBCs in the range between 25 and $50 \mu \mathrm{M}$. Adherence of RBCs to ECs was evaluated from the ratio of $\mathrm{Hb}$ of lysed HUVEC to $\mathrm{Hb}$ of RBCs applied to well. As shown in Figure 11A, HNE treatment induced a significant increase of RBC adherence to ECs, with a value increasing from $0.1 \% \pm 0.01 \%$ with control cells to $1.5 \% \pm 0.3 \%$ and $3.3 \% \pm 0.2 \%$ with HNE-treated RBCs at 25 and $50 \mu \mathrm{M}$, respectively $(p<0.05)$.

RBC adherence to ECs is a physiopathological process eventually leading to endothelial activation and dysfunction, i.e., overexpression of endothelial cell-surface adhesion molecules, such as ICAM-1 [63] . Induced by pro-inflammatory cytokines, these proteins are required for the recruitment and attachment of inflammatory cells across the endothelium of post-capillary venules.

In order to assess whether HNE-induced eryptosis could have also induced EC dysfunction, we finally assessed ICAM-1 levels in ECs co-incubated for $24 \mathrm{~h}$ with either control RBCs or with HNE-stimulated RBCs in the range between 25 and $50 \mu \mathrm{M}$. As shown in Figure 11B, HNE induced a 
significant increase of ICAM-1 levels with a value increasing from $10 \pm 1$ MFI with control RBCs to 51 \pm 3 MFI and $94 \pm 1$ MFI HNE-treated RBCs at 25 and $50 \mu \mathrm{M}$, respectively $(p<0.05)$.

A

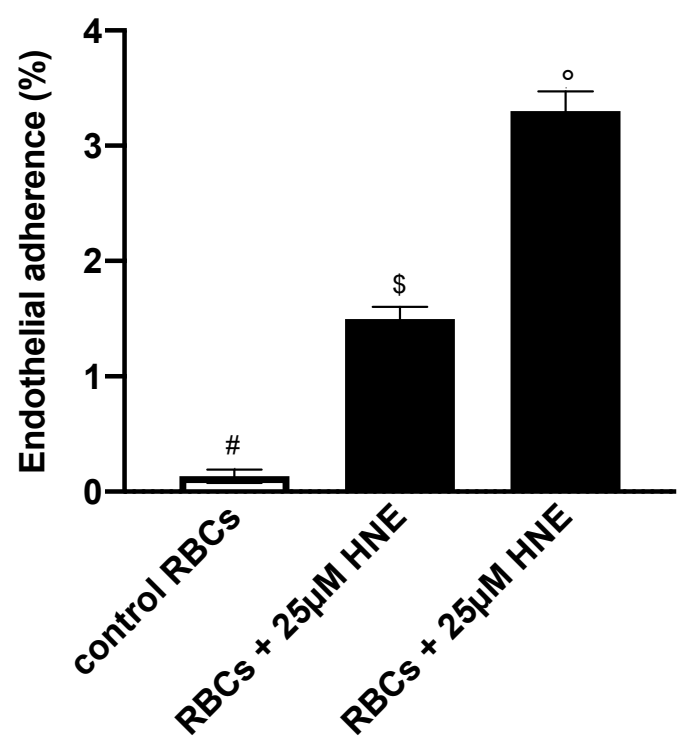

B

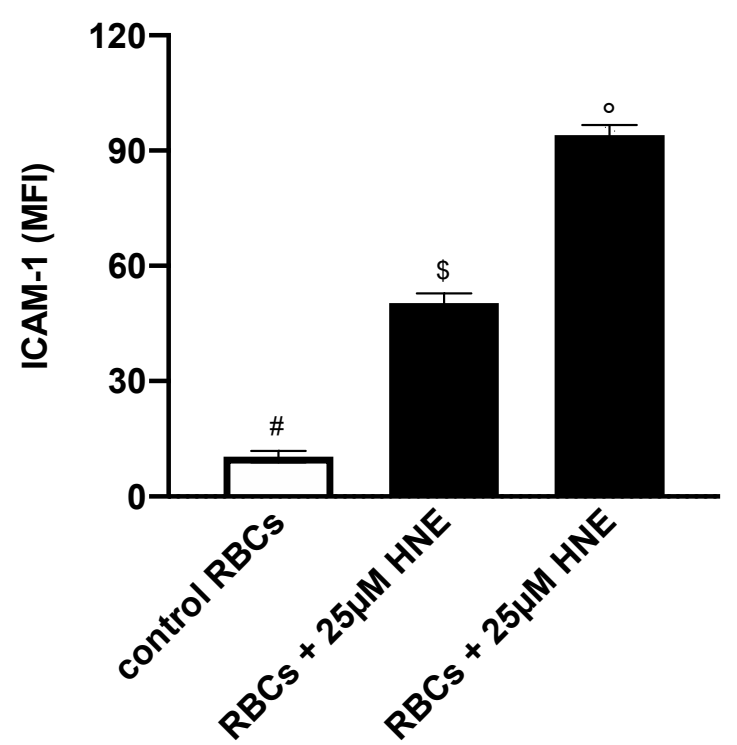

Figure 11. (A) Percentage of adherence to endothelial cells (ECs) of HNE-stimulated RBCs. (B) ICAM-1 expression in ECs co-incubated with HNE-stimulated RBCs: Incubation conditions and measurement of cell adherence or ICAM-1 expression were as reported in the Section 2.8. Controls were HNE-untreated RBCs. Values are means \pm SD of six independent experiments carried out in triplicate. Bars with special characters are significantly different with $p<0.05$ (ANOVA associated with Fisher's correction).

Relevantly, our results demonstrate that HNE-induced eryptosis could foster adhesion of eryptotic RBCs to endothelium and, importantly, lead to its dysfunction. Several pathological conditions, characterized by high plasma levels of $\mathrm{HNE}$, are associated with vascular complications. Our experimental evidences suggest that eryptotic RBCs could contribute to vascular dysfunctions in these diseases.

\section{Conclusions}

In this work, we unveiled for the first time a new physiopathological role for HNE, i.e., its ability to exert eryptotic effects. Mechanistic details of the process pointed out a crucial role for lipid-derived signalling molecules such as ceramide and $\mathrm{PGE}_{2}$ (Scheme 1). SEM analysis demonstrated an altered morphology characteristic of apoptotic RBCs and agglutination elements through which the cells could interact with platelets or ECs. Indeed, we have also shown an increased adhesiveness of eryptotic RBCs to endothelial cells and their consequential dysfunction. As a whole, our results may suggest a new and additional mechanism through which HNE could contribute to the vascular complications characteristic of cardiometabolic and inflammatory-mediated pathologies. 


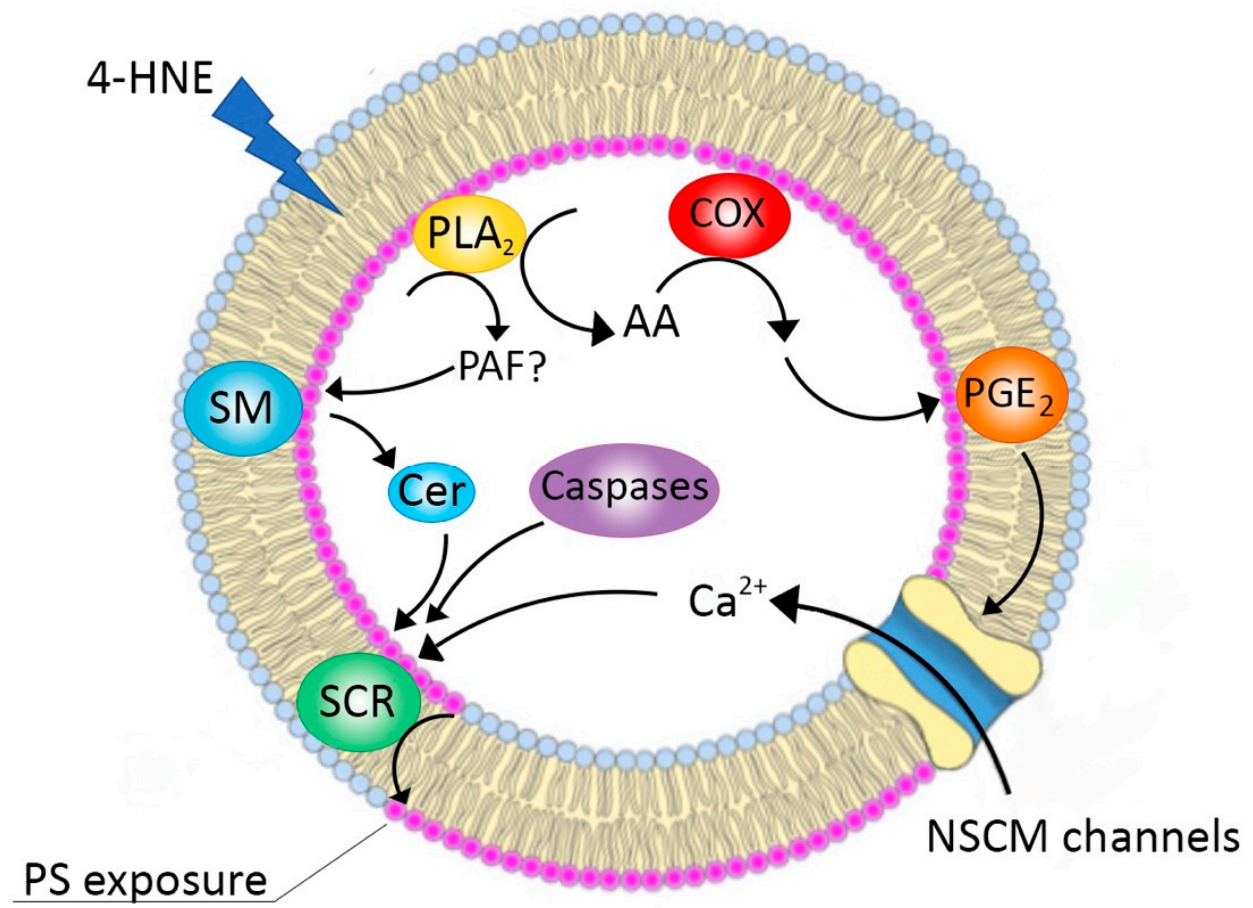

Scheme 1. Schematic representation of the proposed mechanisms for HNE-induced eryptosis. SM: sphingomyelinase; Cer: ceramide; SCR: scramblase; NSCM: non-selective cationic membrane; COX: cyclooxygenase; AA: arachidonic acid; PAF: platelet aggregation factor; $\mathrm{PLA}_{2}$ : phospholipase $\mathrm{A}_{2}$.

Author Contributions: Conceptualization, M.A. and L.T.; methodology, A.F., A.P., A.A. and S.V.; software, I.R.; validation, M.A., L.T. and A.A.; formal analysis, L.T. and M.A.L.; investigation, M.A., A.A. and S.V.; writing-review and editing, M.A. and L.T.; visualization, I.R. and S.V. All authors have read and agreed to the published version of the manuscript.

Funding: This research was funded by PRIN-20157ATSLF_009 (DESIGN: Discovery of molecular and genetic/ epigenetic signatures underlying resistance to age-related diseases and comorbidities).

Conflicts of Interest: The authors declare no conflict of interest.

\section{References}

1. Lang, E.; Qadri, S.M.; Lang, F. Killing me softly-Suicidal erythrocyte death. Int. J. Biochem. Cell Biol. 2012, 44, 1236-1243. [CrossRef] [PubMed]

2. Wesseling, M.C.; Wagner-Britz, L.; Nguyen, D.B.; Asanidze, S.; Mutua, J.; Mohamed, N.; Hanf, B.; Ghashghaeinia, M.; Kaestner, L.; Bernhardt, I. Novel Insights in the Regulation of Phosphatidylserine Exposure in Human Red Blood Cells. Cell. Physiol. Biochem. 2016, 39, 1941-1954. [CrossRef] [PubMed]

3. Qadri, S.M.; Bissinger, R.; Solh, Z.; Oldenborg, P.A. Eryptosis in health and disease: A paradigm shift towards understanding the (patho)physiological implications of programmed cell death of erythrocytes. Blood Rev. 2017, 31, 349-361. [CrossRef] [PubMed]

4. Pretorius, E.; Du Plooy, J.N.; Bester, J. A Comprehensive Review on Eryptosis. Cell. Physiol. Biochem. 2016, 39, 1977-2000. [CrossRef] [PubMed]

5. Lang, F.; Lang, E.; Foeller, M. Physiology and pathophysiology of eryptosis. Transfus. Med. Hemother. 2012, 39, 308-314. [CrossRef] [PubMed]

6. Lang, E.; Lang, F. Triggers, inhibitors, mechanisms, and significance of eryptosis: The suicidal erythrocyte death. BioMed Res. Int. 2015, 2015. [CrossRef]

7. Sarang, Z.; Mádi, A.; Koy, C.; Varga, S.; Glocker, M.O.; Ucker, D.S.; Kuchay, S.; Chishti, A.H.; Melino, G.; Fésüs, L.; et al. Tissue transglutaminase (TG2) facilitates phosphatidylserine exposure and calpain activity in calcium-induced death of erythrocytes. Cell Death Differ. 2007, 14, 1842-1844. [CrossRef] 
8. Esterbauer, H.; Muskiet, F.; Horrobin, D.F. Cytotoxicity and genotoxicity of lipid-oxidation products. Am. J. Clin. Nutr. 1993, 57, 779S-786S. [CrossRef]

9. Esterbauer, H.; Schaur, R.J.; Zollner, H. Chemistry and biochemistry of 4-hydroxynonenal, malonaldehyde and related aldehydes. Free Radic. Biol. Med. 1991, 11, 81-128. [CrossRef]

10. Riahi, Y.; Cohen, G.; Shamni, O.; Sasson, S. Signaling and cytotoxic functions of 4-hydroxyalkenals. Am. J. Physiol. Endocrinol. Metab. 2010, 299, E879-E886. [CrossRef]

11. Subramaniam, R.; Roediger, F.; Jordan, B.; Mattson, M.P.; Keller, J.N.; Waeg, G.; Butterfield, D.A. The Lipid Peroxidation Product, 4-Hydroxy-2-trans-Nonenal, Alters the Conformation of Cortical Synaptosomal Membrane Proteins. J. Neurochem. 2002, 69, 1161-1169. [CrossRef] [PubMed]

12. Strohmaier, H.; Hinghofer-Szalkay, H.; Jörg Schaur, R. Detection of 4-hydroxynonenal (HNE) as a physiological component in human plasma. J. Lipid Mediat. Cell Signal. 1995, 11, 51-61. [CrossRef]

13. Calzada, C.; Colas, R.; Guillot, N.; Guichardant, M.; Laville, M.; Véricel, E.; Lagarde, M. Subgram daily supplementation with docosahexaenoic acid protects low-density lipoproteins from oxidation in healthy men. Atherosclerosis 2010, 208, 467-472. [CrossRef] [PubMed]

14. Pillon, N.J.; Vella, R.E.; Soulère, L.; Becchi, M.; Lagarde, M.; Soulage, C.O. Structural and functional changes in human insulin induced by the lipid peroxidation byproducts 4-hydroxy-2-nonenal and 4-hydroxy-2-hexenal. Chem. Res. Toxicol. 2011, 24, 752-762. [CrossRef] [PubMed]

15. Syslová, K.; Kačer, P.; Kuzma, M.; Najmanová, V.; Fenclová, Z.; Vlčková, Š.; Lebedová, J.; Pelclová, D. Rapid and easy method for monitoring oxidative stress markers in body fluids of patients with asbestos or silica-induced lung diseases. J. Chromatogr. B 2009, 877, 2477-2486. [CrossRef] [PubMed]

16. Grune, T.; Michel, P.; Sitte, N.; Eggert, W.; Albrecht-Nebe, H.; Esterbauer, H.; Siems, W.G. Increased levels of 4-hydroxynonenal modified proteins in plasma of children with autoimmune diseases. Free Radic. Biol. Med. 1997, 23, 357-360. [CrossRef]

17. Smathers, R.L.; Fritz, K.S.; Galligan, J.J.; Shearn, C.T.; Reigan, P.; Marks, M.J.; Petersen, D.R. Characterization of 4-HNE modified L-FABP reveals alterations in structural and functional dynamics. PLoS ONE 2012, 7, e38459. [CrossRef]

18. Forman, H.J. Reactive oxygen species and $\alpha, \beta$-unsaturated aldehydes as second messengers in signal transduction. Ann. N. Y. Acad. Sci. 2010, 1203, 35. [CrossRef]

19. Poli, G.; Schaur, R.J.; Siems, W.G.; Leonarduzzi, G. 4-Hydroxynonenal: A membrane lipid oxidation product of medicinal interest. Med. Res. Rev. 2008, 28, 569-631. [CrossRef]

20. Shoeb, M.; Ansari, N.; Srivastava, S.; Ramana, K. 4-Hydroxynonenal in the Pathogenesis and Progression of Human Diseases. Curr. Med. Chem. 2013, 21, 230-237. [CrossRef]

21. Dalle-Donne, I.; Aldini, G.; Carini, M.; Colombo, R.; Rossi, R.; Milzani, A. Protein carbonylation, cellular dysfunction, and disease progression. J. Cell. Mol. Med. 2006, 10, 389-406. [CrossRef] [PubMed]

22. Aldini, G.; Carini, M.; Yeum, K.J.; Vistoli, G. Novel molecular approaches for improving enzymatic and nonenzymatic detoxification of 4-hydroxynonenal: Toward the discovery of a novel class of bioactive compounds. Free Radic. Biol. Med. 2014, 69, 145-156. [CrossRef] [PubMed]

23. Tesoriere, L.; Attanzio, A.; Allegra, M.; Livrea, M.A. Dietary indicaxanthin from cactus pear (Opuntia ficus-indica L. Mill) fruit prevents eryptosis induced by oxysterols in a hypercholesterolaemia-relevant proportion and adhesion of human erythrocytes to endothelial cell layers. Br. J. Nutr. 2015, 114, 368-375. [CrossRef] [PubMed]

24. Herbst, U.; Toborek, M.; Kaiser, S.; Mattson, M.P.; Hennig, B. 4-hydroxynonenal induces dysfunction and apoptosis of cultured endothelial cells. J. Cell. Physiol. 1999, 181, 295-303. [CrossRef]

25. Liu, W.; Kato, M.; Akhand, A.A.; Hayakawa, A.; Suzuki, H.; Miyata, T.; Kurokawa, K.; Hotta, Y.; Ishikawa, N.; Nakashima, I. 4-hydroxynonenal induces a cellular redox status-related activation of the caspase cascade for apoptotic cell death. J. Cell Sci. 2000, 113, 635-641. [PubMed]

26. Awasthi, Y.C.; Sharma, R.; Cheng, J.Z.; Yang, Y.; Sharma, A.; Singhal, S.S.; Awasthi, S. Role of 4-hydroxynonenal in stress-mediated apoptosis signaling. Mol. Asp. Med. 2003, 24, 219-230. [CrossRef]

27. Sharma, A.; Sharma, R.; Chaudhary, P.; Vatsyayan, R.; Pearce, V.; Jeyabal, P.V.S.; Zimniak, P.; Awasthi, S.; Awasthi, Y.C. 4-Hydroxynonenal induces p53-mediated apoptosis in retinal pigment epithelial cells. Arch. Biochem. Biophys. 2008, 480, 85-94. [CrossRef] 
28. Sharma, R.; Sharma, A.; Dwivedi, S.; Zimniak, P.; Awasthi, S.; Awasthi, Y.C. 4-Hydroxynonenal self-limits Fas-mediated DISC-independent apoptosis by promoting export of Daxx from the nucleus to the cytosol and its binding to Fas. Biochemistry 2008, 47, 143-156. [CrossRef]

29. Awasthi, Y.C.; Sharma, R.; Sharma, A.; Yadav, S.; Singhal, S.S.; Chaudhary, P.; Awasthi, S. Self-regulatory role of 4-hydroxynonenal in signaling for stress-induced programmed cell death. Free Radic. Biol. Med. 2008, 45, 111-118. [CrossRef]

30. Biswas, D.; Sen, G.; Biswas Tuli, T. Reduced cellular redox status induces 4-hydroxynonenal-mediated caspase 3 activation leading to erythrocyte death during chronic arsenic exposure in rats. Toxicol. Appl. Pharmacol. 2010, 244, 315-327. [CrossRef]

31. Vatsyayan, R.; Kothari, H.; Pendurthi, U.R.; Rao, L.V.M. 4-hydroxy-2-nonenal enhances tissue factor activity in human monocytic cells via p38 mitogen-activated protein kinase activation-dependent phosphatidylserine exposure. Arterioscler. Thromb. Vasc. Biol. 2013, 33, 1601-1611. [CrossRef] [PubMed]

32. Chapple, S.J.; Cheng, X.; Mann, G.E. Effects of 4-hydroxynonenal on vascular endothelial and smooth muscle cell redox signaling and function in health and disease. Redox Biol. 2013, 1, 319-331. [CrossRef] [PubMed]

33. Zhang, X.; Wang, Z.; Li, J.; Gu, D.; Li, S.; Shen, C.; Song, Z. Increased 4-Hydroxynonenal Formation Contributes to Obesity-Related Lipolytic Activation in Adipocytes. PLoS ONE 2013, 8. [CrossRef] [PubMed]

34. Pillon, N.J.; Croze, M.L.; Vella, R.E.; Soulère, L.; Lagarde, M.; Soulage, C.O. The lipid peroxidation by-product 4-hydroxy-2-nonenal (4-HNE) induces insulin resistance in skeletal muscle through both carbonyl and oxidative stress. Endocrinology 2012, 153, 2099-2111. [CrossRef] [PubMed]

35. Tesoriere, L.; Attanzio, A.; Allegra, M.; Cilla, A.; Gentile, C.; Livrea, M.A. Oxysterol mixture in hypercholesterolemia-relevant proportion causes oxidative stress-dependent eryptosis. Cell. Physiol. Biochem. 2014, 34, 1075-1089. [CrossRef] [PubMed]

36. Rother, R.P.; Bell, L.; Hillmen, P.; Gladwin, M.T. The clinical sequelae of intravascular hemolysis and extracellular plasma hemoglobin: A novel mechanism of human disease. J. Am. Med. Assoc. 2005, 293, 1653-1662. [CrossRef] [PubMed]

37. Lang, F.; Qadri, S.M. Mechanisms and significance of eryptosis, the suicidal death of erythrocytes. Blood Purif. 2012, 33, 125-130. [CrossRef] [PubMed]

38. Polliack, A. The contribution of scanning electron microscopy in haematology: Its role in defining leucocyte and erythrocyte disorders. J. Microsc. 1981, 123, 177-187. [CrossRef] [PubMed]

39. Coleman, M.L.; Sahai, E.A.; Yeo, M.; Bosch, M.; Dewar, A.; Olson, M.F. Membrane blebbing during apoptosis results from caspase-mediated activation of ROCK I. Nat. Cell Biol. 2001, 3, 339-345. [CrossRef]

40. Arashiki, N.; Otsuka, Y.; Ito, D.; Yang, M.; Komatsu, T.; Sato, K.; Inaba, M. The covalent modification of spectrin in red cell membranes by the lipid peroxidation product 4-hydroxy-2-nonenal. Biochem. Biophys. Res. Commun. 2010, 391, 1543-1547. [CrossRef]

41. Alviz-Amador, A.; Galindo-Murillo, R.; Pérez-González, H.; Rodríguez-Cavallo, E.; Vivas-Reyes, R.; Méndez-Cuadro, D. Effect of 4-HNE Modification on ZU5-ANK Domain and the Formation of Their Complex with $\beta$-Spectrin: A Molecular Dynamics Simulation Study. J. Chem. Inf. Model. 2020. [CrossRef] [PubMed]

42. Uchida, K.; Hasui, Y.; Osawa, T. Covalent attachment of 4-hydroxy-2-nonenal to erythrocyte proteins. J. Biochem. 1997, 122, 1246-1251. [CrossRef] [PubMed]

43. Berg, C.P.; Engels, I.H.; Rothbart, A.; Lauber, K.; Renz, A.; Schlosser, S.F.; Schulze-Osthoff, K.; Wesselborg, S. Human mature red blood cells express caspase-3 and caspase-8, but are devoid of mitochondrial regulators of apoptosis. Cell Death Differ. 2001, 8, 1197-1206. [CrossRef] [PubMed]

44. Carelli-Alinovi, C.; Pirolli, D.; Giardina, B.; Misiti, F. Protein kinase C mediates caspase 3 activation: A role for erythrocyte morphology changes. Clin. Hemorheol. Microcirc. 2015, 59, 345-354. [CrossRef] [PubMed]

45. Carelli-Alinovi, C.; Dinarelli, S.; Sampaolese, B.; Misiti, F.; Girasole, M. Morphological changes induced in erythrocyte by amyloid beta peptide and glucose depletion: A combined atomic force microscopy and biochemical study. Biochim. Biophys. Acta Biomembr. 2019, 186, 236-244. [CrossRef] [PubMed]

46. Grey, J.L.; Kodippili, G.C.; Simon, K.; Low, P.S. Identification of contact sites between ankyrin and band 3 in the human erythrocyte membrane. Biochemistry 2012, 51, 6838-6846. [CrossRef]

47. Lang, K.S.; Lang, P.A.; Bauer, C.; Duranton, C.; Wieder, T.; Huber, S.M.; Lang, F. Mechanisms of suicidal erythrocyte death. Cell. Physiol. Biochem. 2005, 15, 195-202. [CrossRef] 
48. Föller, M.; Kasinathan, R.S.; Koka, S.; Lang, C.; Shumilina, E.; Birnbaumer, L.; Lang, F.; Huber, S.M. TRPC6 contributes to the Ca 2+ leak of human erythrocytes. Cell. Physiol. Biochem. 2008, 21, 183-192. [CrossRef]

49. Schwarzer, E.; Arese, P.; Skorokhod, O.A. Role of the lipoperoxidation product 4-hydroxynonenal in the pathogenesis of severe malaria anemia and malaria immunodepression. Oxid. Med. Cell. Longev. 2015. [CrossRef]

50. Tozoni, S.S.; Dias, G.F.; Bohnen, G.; Grobe, N.; Pecoits-Filho, R.; Kotanko, P.; Moreno-Amaral, A.N. Uremia and hypoxia independently induce eryptosis and erythrocyte redox imbalance. Cell. Physiol. Biochem. 2019, 53, 794-804.

51. Bissinger, R.; Bhuyan, A.A.M.; Qadri, S.M.; Lang, F. Oxidative stress, eryptosis and anemia: A pivotal mechanistic nexus in systemic diseases. FEBS J. 2019, 286, 826-854. [CrossRef] [PubMed]

52. Lang, E.; Lang, F. Mechanisms and pathophysiological significance of eryptosis, the suicidal erythrocyte death. In Seminars in Cell \& Developmental Biology; Academic Press: Cambridge, MA, USA, 2015.

53. Cheng, J.Z.; Sharma, R.; Yang, Y.; Singhal, S.S.; Sharma, A.; Saini, M.K.; Singh, S.V.; Zimniak, P.; Awasthi, S.; Awasthi, Y.C. Accelerated Metabolism and Exclusion of 4-Hydroxynonenal through Induction of RLIP76 and hGST5.8 Is an Early Adaptive Response of Cells to Heat and Oxidative Stress. J. Biol. Chem. 2001, 276, 41213-41223. [CrossRef] [PubMed]

54. Lang, P.A.; Kempe, D.S.; Myssina, S.; Tanneur, V.; Birka, C.; Laufer, S.; Lang, F.; Wieder, T.; Huber, S.M. PGE2 in the regulation of programmed erythrocyte death. Cell Death Differ. 2005, 12, 415-428. [CrossRef] [PubMed]

55. Gargiulo, S.; Rossin, D.; Testa, G.; Gamba, P.; Staurenghi, E.; Biasi, F.; Poli, G.; Leonarduzzi, G. Up-regulation of COX-2 and mPGES-1 by 27-hydroxycholesterol and 4-hydroxynonenal: A crucial role in atherosclerotic plaque instability. Free Radic. Biol. Med. 2018, 129, 354-363. [CrossRef] [PubMed]

56. Zarrouki, B.; Soares, A.F.; Guichardant, M.; Lagarde, M.; Géloën, A. The lipid peroxidation end-product 4-HNE induces COX-2 expression through p38MAPK activation in 3T3-L1 adipose cell. FEBS Lett. 2007, 581, 2394-2400. [CrossRef] [PubMed]

57. Ramana, K.V.; Fadl, A.A.; Tammali, R.; Reddy, A.B.M.; Chopra, A.K.; Srivastava, S.K. Aldose reductase mediates the lipopolysaccharide-induced release of inflammatory mediators in RAW264.7 murine macrophages. J. Biol. Chem. 2006, 281, 33019-33029. [CrossRef] [PubMed]

58. Honma, S.; Takahashi, N.; Shinohara, M.; Nakamura, K.; Mitazaki, S.; Abe, S.; Yoshida, M. Amelioration of cisplatin-induced mouse renal lesions by a cyclooxygenase (COX)-2 selective inhibitor. Eur. J. Pharmacol. 2013, 715, 181-188. [CrossRef]

59. Chen, S.H.; Fahmi, H.; Shi, Q.; Benderdour, M. Regulation of microsomal prostaglandin E2synthase-1 and 5-lipoxygenase-activating protein/5-lipoxygenase by 4-hydroxynonenal in human osteoarthritic chondrocytes. Arthritis Res. Ther. 2010, 12. [CrossRef]

60. Lang, F.; Gulbins, E.; Lang, P.A.; Zappulla, D.; Föller, M. Ceramide in suicidal death of erythrocytes. Cell. Physiol. Biochem. 2010, 26, 21-28. [CrossRef]

61. Borst, O.; Abed, M.; Alesutan, I.; Towhid, S.T.; Qadri, S.M.; Föller, M.; Gawaz, M.; Lang, F. Dynamic adhesion of eryptotic erythrocytes to endothelial cells via CXCL16/SR-PSOX. Am. J. Physiol. Cell Physiol. 2012, 302, C644-C651. [CrossRef]

62. Wautier, J.L.; Wautier, M.P. Molecular basis of erythrocyte adhesion to endothelial cells in diseases. Clin. Hemorheol. Microcirc. 2013, 53, 11-21. [CrossRef] [PubMed]

63. Lawson, C.; Wolf, S. ICAM-1 signaling in endothelial cells. Pharmacol. Rep. 2009, 61, 22-32. [CrossRef]

(C) 2020 by the authors. Licensee MDPI, Basel, Switzerland. This article is an open access article distributed under the terms and conditions of the Creative Commons Attribution (CC BY) license (http://creativecommons.org/licenses/by/4.0/). 